\title{
Relative warps meet cladistics: A contribution to the phylogenetic relationships of baleen whales based on landmark analyses of mysticete crania
}

\author{
OLIVER HAMPE \& SVEN BASZIO
}

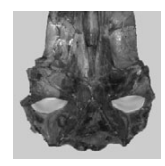

\begin{abstract}
During the last few years research on fossil baleen whales experienced a renaissance. Several important fossils were described, and new and extended cladistic analyses were performed, partly including molecular data from living species. Despite the progress in our knowledge of their phylogeny, many questions have still not been resolved. A different attempt to illustrate mysticete relationships is presented here using landmark analyses. For the present analysis, 38 dorsal views of mysticete skulls and skull reconstructions were scanned and thirteen landmarks were defined. The method used is the relative warp analysis. This method allows a clustering of elements according to their similarity in shape. The calculated relative warps explain main shape variations in the sample. As in parsimony analyses the toothed mysticetes are clearly distinguishable. Representatives of the Aetocetoidea are grouped very closely together and therefore their classification in this family is strongly supported. The performed analysis shows that the crania of the Balaenidae have developed similarities to the cranium of Janjucetus hunderi. The restriction of the Cetotheriidae to a small group of taxa is confirmed here and includes in this analysis Cetotherium, Mixocetus, Piscobalaena, and Titanocetus with a close relationship to the living gray whale. The stem-balaenopterids do not show any clear signals in the present analysis. There is no support for a subdivision into further families. The structure of the dorsal cranium of Protororqualus and Praemegaptera is very similar to that of Balaenoptera. $\bullet$ Key words: Mysticeti, morphometry, landmark analysis, relative warps, relationships, phylogeny.
\end{abstract}

HAMPE, O. \& BASZIO, S. 2010. Relative warps meet cladistics: A contribution to the phylogenetic relationships of baleen whales based on landmark analyses of mysticete crania. Bulletin of Geosciences 85(2), 199-218 (6 figures, 2 tables). Czech Geological Survey, Prague. ISSN 1214-1119. Manuscript received October 30, 2009; accepted in revised form March 1, 2010; published online April 16, 2010; issued June 30, 2010.

Oliver Hampe, Museum für Naturkunde, Leibniz-Institut für Evolutions- und Biodiversitätsforschung an der Humboldt-Universität zu Berlin, Invalidenstraße 43, 10115 Berlin, Germany; oliver.hampe@mfn-berlin.de•Sven Baszio, Steinmann-Institut für Geologie, Mineralogie und Paläontologie, Bereich Paläontologie, Universität Bonn, Nussallee 8, 53115 Bonn, Germany; sven.baszio@web.de

Mysticetes comprise, together with the odontocetes, one of the two living cetacean suborders and are generally known as medium- to large-sized filter feeders. A large, broad rostrum with thin edges formed by loosely sutured bones, the loss of functional teeth, the development of baleen suspended from the palate, a plate-like infraorbital process in the maxilla, and a short mandibular symphysis are the main cranial features of this group.

The evolution of mysticetes was influenced by the palaeogeographic changes in the southern hemisphere, namely the break-off of the southern continent Gondwana and the induction of the circum-antarctic cold water currents, which resulted in a significant event in the Earth's history. Climate and palaeogeography positively influenced plankton productivity, and the growth and flow of nutrient-rich waters (Lipps \& Mitchell 1976; Kennett 1978; Fordyce 1977, 1980a). These played a major role as significant feeding grounds not only for the emerging mysticetes, but also for seals, penguins, and other organisms. Baleen whales developed different ways of foraging by varying their cranial and mandibular anatomy. As documented for the extant representatives, lunge feeding is the strategy of the rorquals of the genus Balaenoptera. The humpback Megaptera developed a sophisticated tactic of group feeding using a curtain of bubbles to trap the food source such as clouds of krill or schooling fish (Jurasz \& Jurasz 1979). Skim feeding is the strategy of the bow-headed Balaenidae (right whales) and bottom feeding that of the gray whale Eschrichtius.

Phylogenetically, mysticetes and odontocetes probably derived from the Dorudontinae, a subfamily of the paraphyletic group, the Basilosauridae, the late diverging archaeocetes of the middle and late Eocene (Uhen 1998). The first mysticete whale (Llanocetus) is known from the 
late Eocene of Seymour Iceland, Antarctica (Mitchell 1989, Fordyce 2003). This basal form still exhibited tooth-bearing jaws. By the early Oligocene, the first toothless baleen whales had evolved (Marples 1956, Okazaki 1994, Sanders \& Barnes 2002a). Due to palaeogeographical and oceanic developments, baleen whales occurred in the northern hemisphere not before the late Oligocene (Rothausen 1971, Sanders \& Barnes 2002a). During the Miocene, radiation towards modern mysticetes occured, very probably from a large group of fossils, which were categorised under the name "cetotheres". The evolutionary history of the balaenids and neobalaenids has not yet been fully resolved (Fordyce \& Muizon 2001, Bisconti 2003). Several homoplastic developments in the morphology are attributed to their specific adaptation to life in water (behaviour, diet), which makes it difficult to interpret the phylogenetic relationships. Additionally, a large quantity of taxa are badly preserved or known from only undiagnostic remains. By the end of the Miocene, baleen whales developed the bodystructure of recent species, one of which is the blue whale, the largest animal that ever lived. During the last few years several newly discovered fossils were described, and new and extended cladistic analyses were executed, some including molecular data from the living species (Fig. 1).

The monophyly of mysticetes has never been in serious doubt (Geisler \& Sanders 2003). However, the evolutionary processes within this group are not completely understood. Despite the progress made in our knowledge of mysticete phylogeny, some important questions still remain unanswered. The phylogenetic roots of modern whales, such as balaenopterids and balaenids, are still under discussion (Fraser \& Dooley 2002). In this paper, a new attempt to investigate mysticete relationships using landmark analyses will be presented. The idea is to compare and test the results of recently published phylogenies with an alternative morphometric approach. The results of the landmark analyses, which are based on a limited number of characters (see "Material and methods") and which originate from a principal components analysis of shapes, often show a similar pattern in related forms that one can also find in classic parsimony analyses. The skull anatomy, es- pecially in the basicranial region and the ear bone morphology, provide the most important characters that are valuable for phylogenetic discussions.

Entire biological structures are taken into account by landmark analyses - this is a huge advantage in comparison to other methods used for morphological analyses which focus on single "characters" that are not put into context with one another (Baszio \& Weber 2002). In this paper we study shape changes in the whole skull. The perception that there is a tendency for the skull to elongate during baleen whale evolution is rather trivial. Landmark analyses, however, allow determination of how the skull grew longer and which skull elements were involved in the elongation. At the same time, smaller shape changes may have occured in the posterior part of the skull which might previously have been overlooked due to the overwhelming shape change caused by the skull elongation. These smaller - albeit perhaps decisive - changes become apparent with morphometrics, especially landmark analysis methods. Landmark analyses and morphometrics in general can be instrumental in discovering new characters or character states to the extent that the use of these tools can inform systematics about morphological discontinuities that exist within nature (MacLeod 2001, 2002). However, statements about systematic relationships must be drawn with care from a landmark analysis because the starting-point for this method applied here is a consensus configuration that is an "average shape" of all specimens in the sample. In contrast, cladistic analyses refer to an outgroup taxon.

A comprehensive and fundamental work on the method of landmark analyses was presented by Bookstein (1991). Since then it has been applied to a variety of organisms in order to investigate taxonomic and functional shape changes (e.g., Baylac \& Daufresne 1996, Loy et al. 1996, Sarà 1996). Landmark-based phylogenetic discussions in vertebrate palaeontology are to date rare, e.g. O'Keefe (2002) on plesiosaurs, Baszio (2005) on boid snake vertebrae, Stayton \& Ruta (2006) on temnospondyl crania, Anderson (2008) on arthrodire jaws and Samuels \& Valkenburgh (2009) on late Oligocene and early Miocene beaver skulls.

Figure 1. Cladograms explaining the phylogenetic relationships of the Mysticeti. $\bullet$ A - Bisconti (2007/2008), strict consensus of nine equally parsimonious trees (PAUP 4.0b10); 165 morphological characters; tree length 503 steps, CI = 0.5447, RI =0.8115. $\bullet$ B - Bouetel \& Muizon (2006), strict consensus of three obtained trees after reweighting of characters (PAUP 4); 101 morphological characters; $\mathrm{CI}=0.767, \mathrm{RI}=0.896$. $\bullet \mathrm{C}-\mathrm{Deméré}$ et al . (2008), one of six optimal cladograms derived from parsimony analysis (PAUP 4.0b10; TreeRot.v2c for Bremer support calculations; MrBayes 3.1.1 for Bayesian analysis); supermatrix including 27,340 characters, morphological and genomic; tree length 11,998 steps, RI = 0.495. $\bullet$ D - Deméré $e t$ al. (2005), strict consensus of 21 most parsimonious trees with bootstrap and branch support values (PAUP 4.0b10 with maximum parsimony optimality criterion; TreeRot.v.2), 85 morphological characters, tree length 302 steps, $\mathrm{CI}=0.5397, \mathrm{RI}=0.7146$. $\bullet \mathrm{E}-\mathrm{Fitzgerald}(2006)$, strict consensus of three trees derived from parsimony analysis (PAUP 4.0b); 266 morphological characters, 1,167 steps, CI = 0.4790, RI =0.5679. $\bullet \mathrm{F}-\mathrm{Kimura} \&$ Ozawa (2002), 50\% majority-rule consensus tree (PAUP 3.0s, MacClade 3.08a); 77 morphological characters of 108 equally parsimonious trees; tree length 133 steps, $\mathrm{CI}=0.698, \mathrm{HI}=0.304 . \cdot \mathrm{G}-$ Steeman (2007), strict consensus of six most parsimonious trees (PAUP 3.1.1); 69 morphological characters; tree length 134 steps, $\mathrm{CI}=0,82, \mathrm{RI}=0,92$. 
Oliver Hampe \& Sven Baszio • Relative warps meet cladistics: A contribution to the phylogenetic relationships
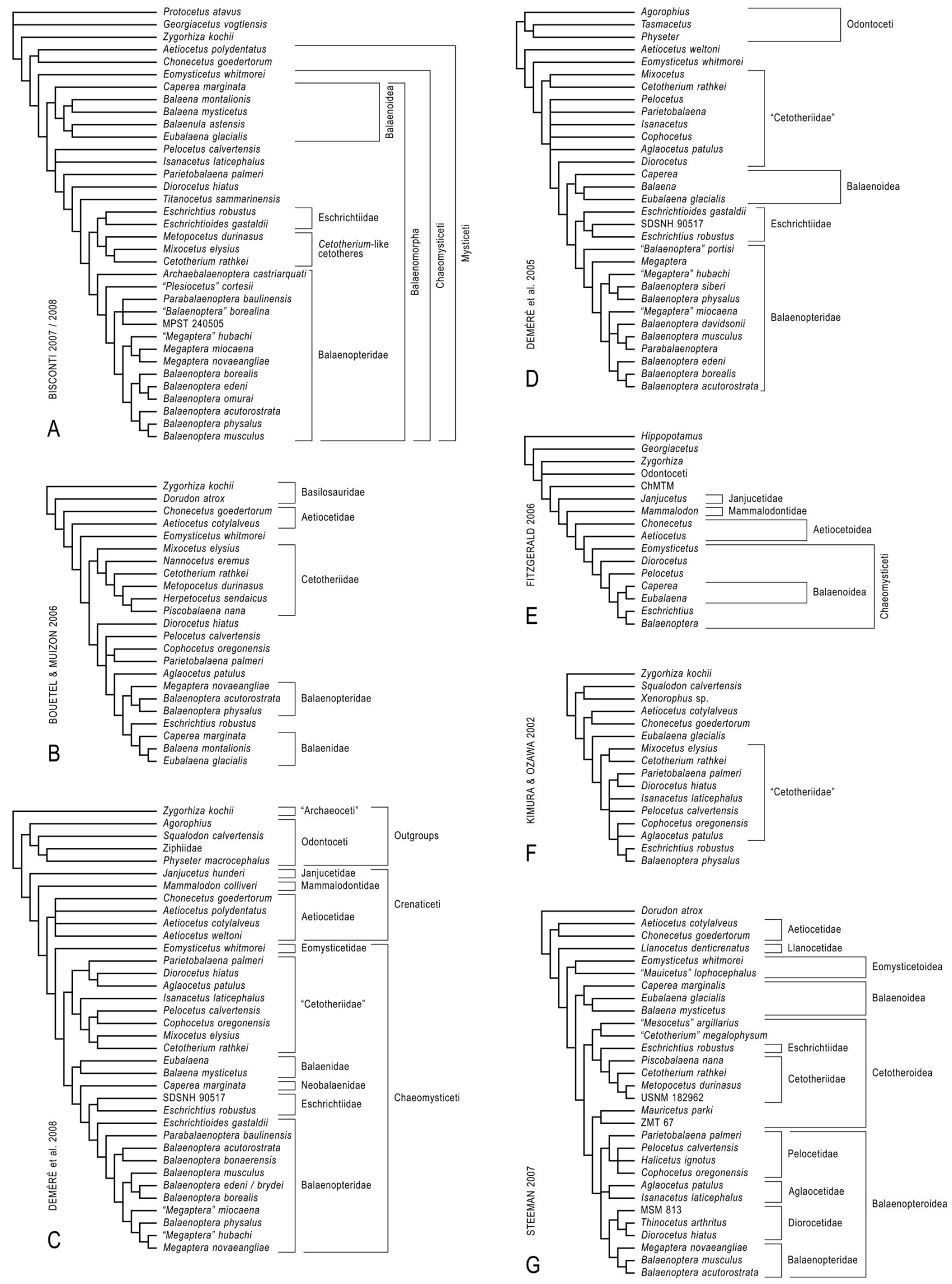


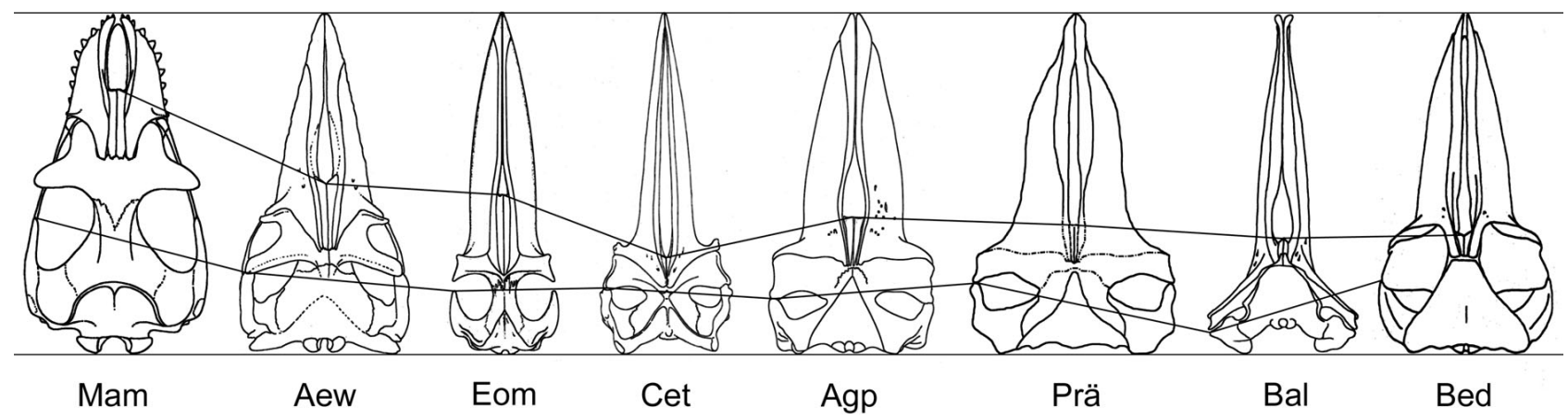

Figure 2. Examples of typical mysticete skulls in dorsal view (illustrated at the same scale with landmarks 2 (anterior end of the nasal at the medial margin) and 8 (anterior end of the zygomatic process) connected in each specimen for comparison: the early mysticete Mammalodon colliveri (Mam; after Fordyce \& Muizon 2001); a typical representative of the Aetiocetidae, Aetiocetus weltoni (Aew; after Barnes et al. 1994); a typical representative of the Eomysticetidae, Eomysticetus whitmorei (Eom; after Sanders \& Barnes 2002b); the type species of the Cetotheriidae, Cetotherium rathkei (Cet; after Pilleri 1986); a representative of the large group of stem-balaenopterids, Aglaocetus patulus (Agp; after Kellogg 1968a); the recently reconstructed (?)balaenopteroid Praemegaptera pampauensis (Prä; Hampe, in prep.); the living balaenid Balaena mysticetus (Bal; after Cuvier 1823); a representative of the living rorquals, Balaenoptera edeni (Bed; after Omura 1959).

\section{Material and methods}

Landmarks are defined as relocatable coordinate positions on an object in an Euclidean measurement space (Bookstein 1991), here two-dimensional. They should be defined on characteristic structures of the studied specimens. It is a prerequisite that every landmark is present in each single specimen included in the study. The dorsal view of the mysticete skull was chosen because a reasonable number of taxa showed consistent structures for the definition of landmarks (Fig. 2). A landmark analysis of the ventral aspect of the skull would be highly desirable. However, it could not be included because diagnostic characters were not visible, accessible or preserved in all the specimens that were analysed in dorsal view. In addition, there are only a few well-known fossil basicrania.

\section{Dataset}

The landmarks for this study are defined from the dorsal view, specifically the norma dorsalis, of well-documented extant and extinct baleen whales. 165 valid taxa have been identified to date (Uhen 2010). However, the majority of described species belong to incomplete fossil species and are considered to be invalid (> 300; Uhen 2010). Eleven extant and 27 fossil species matching the requirements were selected for the present analysis. Many of the selected fossil species have been studied by the first author during many years of research.

Thirty-eight dorsal photographs of whale skulls and recognized skull reconstructions from the literature were scanned on a flat-bed scanner (for information on the selected specimens such as source, region of discovery, age, see Table 1). Thirteen landmarks were defined on suture crossings, structure boundaries, and other characteristic features in dorsal view (Table 2). All determined landmarks are unambiguous, and all appear in the selected 38 specimens, one of the essential requirements. Widely accepted reconstructions were included. Cetotherium rathkei originally lacked the rostral part of the skull, but with the nearly complete right dentary this enabled a reliable reconstruction including the extension and width of the rostrum (Van Beneden \& Gervais 1868, pl. XVII; Brandt 1873, pl. II; Pilleri 1986, fig. 15a). "Mauicetus" lophocephalus is to date only identified from a line drawing - the original holotype skull is lost (Fordyce 1991). We are aware that this might be a source of error in the analysis, but until a revision of the species in question is presented, we have to work with the current knowledge. Furthermore, five landmarks were taken from one side of the skull in Janjucetus hunderi and mirrored along the longitudinal axis to the opposite side because of the incomplete preservation of the specimen ( $>$ bilateral symmetry). In addition, we reconstructed one landmark in the skulls of Otradnocetus virodovi (anterior end of the premaxilla) and Archaebalaenoptera castriarquati cranium (posterior end of the skull).

\section{Landmark analysis applied}

The set of landmarks was manually identified on the left half of the crania from every digitalized photograph or reconstruction; the respective coordinates of all landmarks were documented and transferred into a data matrix. Of the various options for analyzing landmarks, the relative warp analysis was chosen in the present study. This method clusters elements according to their shape similarity by applying a principal component analysis on the landmark configurations in every specimen (Rohlf 1997a, b). The calculated relative warps explain the 
Oliver Hampe \& Sven Baszio • Relative warps meet cladistics: A contribution to the phylogenetic relationships

Table 1. The 38 mysticete species used in the presented landmark analysis (tpsSmall 1.08; tpsRelw 1.13).

\begin{tabular}{|c|c|c|c|c|}
\hline Taxon (Abbrev.) & Source / Reference & Locality / Distribution & Age & Specimen \# \\
\hline Aetiocetus cotylalveus (Aec) & Emlong (1966, fig. 3) & Oregon, USA & late Oligocene & USNM 25210 \\
\hline Aetiocetus polydentatus (Aep) & Barnes et al. (1994, fig. 21) & Japan & late Oligocene & AMP 12 \\
\hline Aetiocetus weltoni (Aew) & Barnes et al. (1994, fig. 18) & Oregon, USA & late Oligocene & UCMP 122900 \\
\hline Aglaocetus moreni (Agm) & Kellogg (1934a, fig. 1) & Argentina & early Miocene & FMNH P.13407 \\
\hline Aglaocetus patulus (Agp) & Kellogg (1968a, fig. 74) & Virginia, USA & early Miocene & USNM 23690 \\
\hline $\begin{array}{l}\text { Archaebalaenoptera castriarquati } \\
\text { (Arc) }\end{array}$ & Bisconti (2007, text-fig. 3) & N Italy & late Pliocene & MGPC SBAER 240536 \\
\hline Balaena mysticetus (Bal) & Cuvier (1823, Pl. XXVI, fig. 10) & Arctic & Recent &. \\
\hline Balaenoptera acutorostrata (Bac) & True (1904, Pl. 22, fig. 1) & Worldwide & Recent & USNM 20931 \\
\hline Balaenoptera borealis (Bbo) & Andrews (1916, Pl. XLI) & Worldwide & Recent & AMNH 34871 \\
\hline Balaenoptera edeni (Bed) & Omura (1959, Pl. 1, fig. 1) & Subtropics,Tropics & Recent & "Ayukawa" specimen \\
\hline Balaenoptera hubachi (Bhu) & Dathe (1983, Abb. 2) & N Chile & early Pliocene & MB Мa. 28570 \\
\hline Balaenoptera musculus (Bmu) & Brown (1995, fig. 150) & N Hemisphere & Recent & $?$ \\
\hline Balaenoptera omurai (Bom) & Wada et al. (2003, fig. 1a) & W Pacific, E Indian Ocean & Recent & NSMT-M32505 \\
\hline Balaenoptera physalus (Bph) & True (1904, Pl. 1, fig. 3) & Worldwide & Recent & USNM 16039 \\
\hline Balaenoptera siberi (Bsi) & Pilleri (1989, Abb. 3) & Peru & late Miocene & SMNK-PAL. 6594 \\
\hline Caperea marginata (Cap) & Baker (1985, fig. 3A) & S Hemisphere & Recent & $?$ \\
\hline Cetotherium rathkei (Cet) & Pilleri (1986, Abb. 15) & Ukraine & middle/late Miocene &. \\
\hline Chonecetus goedertorum (Cho) & Barnes et al. (1994, fig. 10a) & Oregon, USA & late Oligocene & LACM 131146 / 138027 \\
\hline Cophocetus oregonensis (Cop) & Kellogg \& Packard (1934, fig. 2) & Oregon, USA & middle Miocene & UOMNH 305 \\
\hline Diorocetus hiatus (Dio) & Kellogg (1968b, fig. 53) & Maryland, USA & early Miocene & USNM 16783 \\
\hline Eomysticetus whitmorei (Eom) & Sanders \& Barnes (2002b, fig. 3) & South Carolina, USA & late Oligocene & ChM PV 4253 \\
\hline Eschrichtius robustus (Esc) & Andrews (1914, Pl. 25, fig. 2) & N Pacific & Recent & AMNH 34260 \\
\hline Eubalaena glacialis (Eub) & Allen (1908, Pl. XX) & Temperate, Arctic & Recent & $\mathrm{MCZ}$ - no number \\
\hline Isanacetus laticephalus (Isa) & Kimura \& Ozawa (2002, fig. 2) & Japan & early Miocene & MFM $28501 / 18004$ \\
\hline Janjucetus hunderi (Jan) & Fitzgerald (2006, fig. 1a) & Victoria, Australia & late Oligocene & NMV P. 216929 \\
\hline Mammalodon colliveri (Mam) & Fordyce \& Muizon (2001, fig. 10A) & Victoria, Australia & late Oligocene & NMV P. 199986 \\
\hline “Mauicetus” lophocephalus (Mau) & Marples (1956, fig. 1C) & New Zealand & early Oligocene & lost \\
\hline Megaptera novaeangliae (Meg) & True (1904, Pl. 29, fig. 2) & Worldwide & Recent & USNM 21492 \\
\hline Mixocetus elysius (Mix) & Kellogg (1934b, fig. 1) & California, USA & late Miocene & LACM 882 \\
\hline Otradnocetus virodovi (Otr) & Mchedlidze (1984b, Pl. XXI) & N Caucasus & middle Miocene & DIPT CO.I-90 \\
\hline Parabalaenoptera baulinensis (Par) & Zeigler et al. (1997, fig. 6) & California, USA & late Miocene & CASG 66660 \\
\hline Parietobalaena palmeri (Pap) & Kellogg (1968c, fig. 78) & Maryland, USA & early Miocene & USNM 10677 \\
\hline Pelocetus calvertensis (Pel) & Kellogg (1965, fig. 1) & Maryland, USA & early Miocene & USNM 11976 \\
\hline Pinocetus polonicus (Pin) & \multicolumn{2}{|c|}{ Czyzewska \& Ryziewicz (1976, fig. 1) Poland } & middle Miocene & PAS MZ VIII/Vm-7 \\
\hline Piscobalaena nana (Pis) & Bouetel \& Muizon (2006, fig. 5B) & Peru & early Pliocene & MNHN SAS 1617 \\
\hline Praemegaptera pampauensis (Prä) & Hampe, in prep. & N Germany & middle/late Miocene & MNU 071-19 \\
\hline Protororqualus cuvieri (Pro) & Van Beneden (1875, fig. 1) & N Italy & late Pliocene & destroyed WW II \\
\hline Titanocetus sammarinensis (Tit) & Bisconti (2006, fig. 2A) & San Marino & middle Miocene & MGB 1CMC 1729073 \\
\hline
\end{tabular}



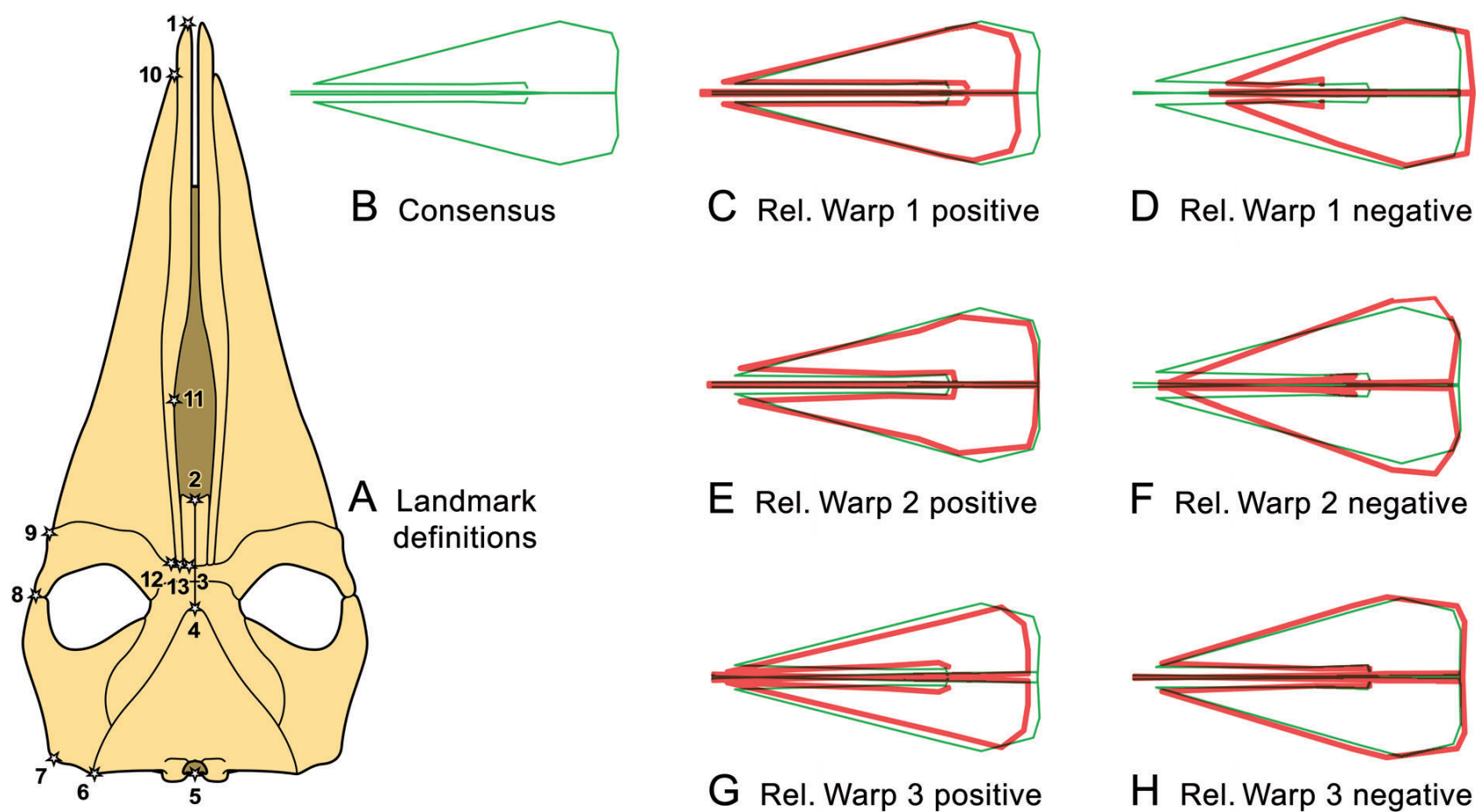

E Rel. Warp 2 positive

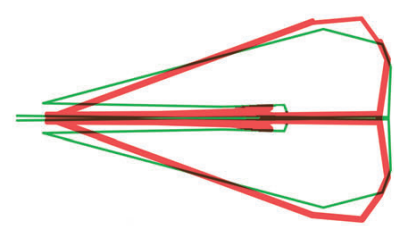

F Rel. Warp 2 negative

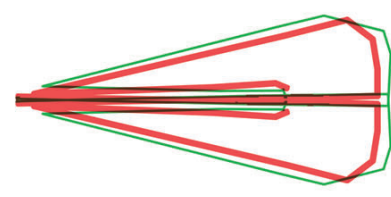

G Rel. Warp 3 positive

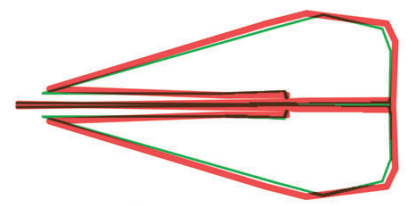

H Rel. Warp 3 negative

Figure 3. Landmark definitions on the dorsal side of a generalized mysticete skull (A; list of the landmarks, see Table 2), consensus configuration (B) and relative warps 1-3 (C-H) that resulted from the landmark analysis. For clearer understanding, all landmarks were connected by lines, resulting in a "wire model" of the dorsal aspect of the mysticete cranium. The green wire model shows the calculated consensus configuration, i.e. the average shape of all specimens in the sample. The respective pairs of positive and negative relative warps (red) are printed on top of the consensus configuration to show the shape changes that are represented by the relative warp.

main shape variations, that is the "principal shape components", in the sample. The outcome is a clustering of various shapes in a shape matrix that can be analyzed and be further discussed in a phylogenetic context. The authors consider this method to be the most genuine and neutral approach to interpret landmark data. Other methods

Table 2. Chosen landmarks for the current warp analysis.

\footnotetext{
1 anterior end of the premaxilla

2 anterior end of the nasal at the medial margin

3 posterior end of the nasal at the medial margin

4 anteriormost point of the supraoccipital shield

5 posterior end of the skull (point between occipital condyles $=$ lower margin of foramen magnum)

6 ventro-lateral point of the supraoccipital shield

7 most lateral point of the postglenoid process (on the lateral face)

8 anterior end of the zygomatic process

9 anterior end of the supraorbital process

10 anteriormost point of maxilla

11 point of maximum breadth of the mesorostral fossa

12 point of maximum length of the maxillar ascending process

13 posterior end of the premaxilla
}

require defining one specimen as a reference point for all other specimens in the sample - an approach that strongly influences the results (Baszio \& Weber 2002).

All calculations were made using the TPS program package, including tpsSmall ver. 1.08 (Rohlf 1997a) and tpsRelw ver 1.13 (Rohlf 1997b). In the first step, the matrix was examined with the tpsSmall program in order to confirm that the shape variance between the various landmark sets is not too large for a relative warp analysis. The relative warp analysis was performed using the tpsRelw programme which assesses the global diversity of the shape variation in the sample. This program places the various specimens (represented by their respective landmark configurations) into a coordinate system according to their similarities in shape, ignoring all size differences.

At first, a consensus configuration is calculated (Fig. 3B). This is the average shape of all specimens in the sample - size differences being ignored. The consensus configuration is represented by the intersection of the two axes in the coordinate system. The axes represent the relative warps or the defined shape changes from the consensus configuration. The farther a given specimen is plotted along the direction of an axis (i.e. the higher the values in the respective relative warp are), the more the represented specimen differs from the calculated consensus configuration. In order to visualize a relative warp, its highest value 
in the coordinate system (i.e. the end of the respective axis) representing a specific landmark configuration is superimposed over the consensus configuration. The landmarks of consensus configurations and the relative warps were connected to each other and mirrored along the longitudinal skull axis in order to produce a wire model. Differences become apparent and show the movement of landmarks relative to the consensus configuration (Fig. $3 \mathrm{C}-\mathrm{H}$ ). The differences between the consensus and the relative warp configurations can be visualized by vectors showing the displacement of every landmark. We chose the grid-model method superimposing the relative warp on the consensus configuration. It is important to note that positive values on one relative warp axis code for defined landmark displacements in a certain direction. Negative values on the same axis code for a displacement of the same landmark in the opposite direction.

The coordinate system thus represents a shape space and the specimens are clustered in this space according to their shape similarities. Every relative warp accounts for a certain amount of variation in the sample. This amount is given as a percentage value for every relative warp.

\section{Institutional abbreviations}

AMNH, American Museum of Natural History, New York AMP, Ashoro Museum of Paleontology, Hokkaido, Japan CASG, California Academy of Sciences, Department of Geology, San Francisco, California

ChM, The Charleston Museum, Charleston, South Carolina

DIPT, L. Davitashvili Institute of Palaeobiology, Tblissi, Georgia

FMNH, The Field Museum, Chicago

LACM, Natural History Museum of Los Angeles County, Los Angeles, California

MB, Museum für Naturkunde Berlin, Germany

MCZ, Museum of Comparative Zoology, Harvard University, Cambridge, Massachusetts

MGB, Museo Geologico Giovanni Capellini, Bologna, Italy

MGPC, Museo Geopaleontologico G. Cortesi, Castell' Arquato, Italy

MFM, Mizunami Fossil Museum, Gifu, Japan

MNHN, Museum National d'Histoire Naturelle, Paris, France

MNU, Museum für Natur und Umwelt Lübeck, Germany

MPST, Museo Paleontologico di Salsomaggiore Terme, Italy

MSM, Museum Sønderjylland, Naturhistorie og Palæontologi, Gram, Denmark

NMV, Museum Victoria, Melbourne, Australia

NSMT, National Science Museum Tokyo, Japan
PAS, Polish Academy of Sciences, Museum of the Earth, Warsaw, Poland

SDSNH, San Diego Natural History Museum, California

SMNK, Staatliches Museum für Naturkunde Karlsruhe, Germany

UCMP, University of California Museum of Paleontology, Berkeley, California

UOMNH, University of Oregon Museum of Natural History, Eugene, Oregon

USNM, National Museum of Natural History, Smithsonian Institution, Washington, D.C.

ZMT, Canterbury Museum, Christchurch, New Zealand

\section{Systematic overview}

The current molecular clock estimates indicate that the divergence of whales from artiodactyls took place $60 \mathrm{Ma}$ ago, an age which compares well with the first appearances of fossil whales around 53.5 Ma, and artiodactyls at $55 \mathrm{Ma}$ (Gingerich 1989, Bajpai \& Gingerich 1998, Theodor 2004, Thewissen et al. 2007). Furthermore, molecular data document an explosive evolutionary radiation of ancestral cetaceans during the period between $35 \mathrm{Ma}$ and $30 \mathrm{Ma}$ (late Eocene-early Oligocene), a time when mysticetes and odontocetes diverged (Árnason et al. 2004). These calibrations generally conform with the fossil record, and also the first occurrence of the fossil mysticete Llanocetus denticrinatus (Mitchell 1989).

\section{Crenaticeti}

The taxon Crenaticeti was introduced by Mitchell (1989) while describing the remains of Llanocetus denticrenatus, the oldest known putative mysticete from the Antarctic La Meseta Formation (Eocene/Oligocene boundary) of Seymour Island. Members of the obviously paraphyletic Crenaticeti are characterized by the presence of functional teeth in both upper and lower jaws in the adult stage. Fordyce \& Barnes (1994) consider the validity of the infraorder Crenaticeti as uncertain. Unfortunately, only fragments of the dentary, the maxilla, both with a few basilosaurid-like teeth in situ, and a cranial endocast constitute the type material of Llanocetus denticrenatus. The later unearthed adjacent skull and remaining dentary, definitely belonging to the holotype, are momentarily under study (Fordyce 2003).

Mammalodon colliveri is a small, enigmatic and monotypic mysticete of the late Oligocene from Victoria, Australia (Pritchard 1939) which has a short rostrum showing differentiated skull kinetics. Certainly, this morphologically extremely derived form (containing only the holotype) was macrophagous - its palate region reveals no clear traces of the presence of baleen, e.g. impressions of nutrient 
channels on the ventral side of the maxillae (Deméré et al. 2008: Fig. 1d, e; of Aetiocetus weltoni).

The bizarre looking Janjucetus hunderi from the late Oligocene Jan Juc Marl near Torquay, Victoria, Australia, has a relatively compact and short, triangular skull. Apomorphic characters regarding the dorsal aspect of the skull are: premaxillae adjacent and anterior to the level of the $\mathrm{P}^{2}$, overhanging the anterior half of the rostrum, and ascending process of the premaxilla in line with both the anterior half of the supraorbital process of the frontal (see details in Fitzgerald 2006). Like Mammalodon, Janjucetus is interpreted as being a marcophagous predator. There is also no evidence hinting to the presence of baleen (see above). The robust skull of Janjucetus, with slightly elongated cranium and the development of caniniform teeth indicates a masticatory system comparable to that found in the living leopard seal Hydrurga leptonyx and in extinct pliosauroids and thus a feeding ability that is analogous to these organisms (Fitzgerald 2006).

The genus Aetiocetus was introduced by Emlong (1966) who described a partial skeleton of A. cotylalveus as an archaeocete, primarily on the presence of teeth. Van Valen (1968) was the first to demonstrate that the cranial bones of Aetiocetus have a close relationship to the mysticetes and that the retention of teeth may be a strongly primitive character. Other authors considered aetiocetids as intermediates between Archaeoceti and Mysticeti because the general proportions of the cranium resemble typical archaeocetes, but the molar teeth are of a different shape similar to those found in archaeocetes (e.g., Whitmore \& Sanders 1976, Mchedlidze 1984a). Today, there is no doubt about the mysticete affiliation of the Aetiocetidae. They definitely share a number of mysticete characters such as the elongated flat rostrum, elongated nasal bones, a well-developed, broad, prominent supraobrital process, massive zygomatic processes, and in particular the triangular outline of the supraoccipital in the dorsal aspect of the cranium (Barnes \& McLeod 1984, Barnes et al. 1994). The Aetiocetidae seemed to be widespread and diversified in the North Pacific realm during the late Oligocene (Ichishima 2005). Three species of Aetiocetus could be included to our analysis, A. cotylalveus and A. weltoni from the Yaquina Formation of Lincoln County, Oregon (the latter stratigraphically of slightly younger age; Barnes et al. 1994), and A. polydentatus from the Morowan Formation of Hokkaido, Japan. The inclusion of the latter species in the genus Aetiocetus is doubtful (see Ichishima 2005: the presence of a parasagittal crest, ventral bending of the lateral maxillar margins and higher number of teeth indicate a different feeding mode), but this problem cannot be resolved with the relative warp analysis used in this paper.

The well-preserved cranium of Chonecetus goedertorum, another aetiocetid from the latest Oligocene of Clallam County, Washington, included in the present anal- ysis, has a comparatively long and tapered rostrum. The cranium differs from Aetiocetus in having a smaller supraoccipital shield, short, thick postorbital processes on the frontals, and small and somewhat rectangular zygomatic processes on the squamosals in dorsal view (Barnes et al. 1994). Chonecetus has, like Aetiocetus, jaws with multicuspid teeth and nutrient foramina and imprints on the ventral side of the maxilla for blood vessels (possibly indicating the presence of baleen). All aetiocetids still show the same dental formulas as in primitive eutherian mammals (3I, 1C, 4P, 3M; see Barnes et al. 1994). The typical multicuspid premolars and molars are derived from the archaeocete pattern. It is assumed, that these toothed mysticetes used their interlocked denticulate teeth for filter-feeding as in the extant crab-eater seal Lobodon carcinophaga (Mitchell 1989, Fordyce \& Muizon 2001, Adam \& Berta 2002, Ichishima 2005).

The aetiocetids Ashorocetus, Morawanocetus, and Willungacetus (Barnes et al. 1994, Pledge 2005) could not be considered here because of the incompleteness of the preserved crania.

\section{Chaeomysticeti}

The most archaic toothless mysticetes known so far are the eomysticetids, introduced by Sanders \& Barnes (2002b), based on two species, Eomysticetus whitmorei and E. carolinensis, of late Oligocene age from South Carolina. Characters seen from the dorsal aspect of the cranium are a long rostrum, nares which are placed in the mid-length of the rostrum, extremely long nasals, parietals exposed along the intertemporal region between the frontals and the supraoccipital, and extremely long zygomatic processes on the squamosals (Sanders \& Barnes 2002b). The braincase is still quite similar to that known in the archaeocetes. The stage of cranial telescoping is less developed. More advanced telescoped specimens are already known from contemporaneous toothed mysticetes (Aetiocetidae) and from other contemporaneous baleen-bearing representatives. The Eomysticetidae form a monophyletic group of primitive baleen-bearing mysticetes (after Geisler \& Sanders 2003) together with the Cetotheriopsidae (including Cetotheriopsis and Micromysticetus, see detailed descriptions in Rothausen 1971, Sanders \& Barnes 2002a; not considered here for preservational reasons). They share several synapomorphies in the ear bone morphology. The Tethyan Cetotheriopsis lintianus and the North Sea species Micromysticetus tobieni are the only known toothless mysticetes from the northern hemisphere discovered from Oligocene strata.

The systematic and taxonomic position of the genus Mauicetus is still under debate (Fordyce 1980b, 1991). The type species, $M$. parki, consists of an incomplete skull coming from the Oligocene/Eocene boundary of South 
Otago, New Zealand (Benham 1937). Later, Marples (1956) described three new species which he referred to Mauicetus, among them "M." lophocephalus from the late Oligocene of North Otago. Fordyce (1991) pointed out, that none of Marples' species are congeneric with Mauicetus.

All more advanced chaeomysticetes, the Neogene Cetotheriidae, stem-balaenopterids, and the extant mysticetes, are grouped within the Balaenomorpha, a clade that shares the cranial characters of a pronounced median keel on the palate region and narrow posterior halves of the nasals (Geisler \& Sanders 2003). In addition they have a number of characters in common in the periotic and tympanic regions.

The Cetotheriidae was a problematic taxon which contained numerous genera and species from the Miocene to early Pliocene. More than 100 species have been ascribed to the family Cetotheriidae (Steeman 2007), a taxon used in the $20^{\text {th }}$ century as a waste basket. Many species included in this assemblage are there based on undiagnostic material. Today, the Cetotheriidae are restricted to a small number of genera (Bouetel \& Muizon 2006; see below). We follow Fordyce (2002a) and call the remaining non-Cetotheriidae "stem-balaenopterids" and "stem-balaenids" until the systematic relationships between the primitive baleen-bearing whales and the modern mysticetes are clarified.

The extinct Balaenomorpha have a world-wide distribution and are documented from North America (e.g., Kellogg 1924, Uhen et al. 2008), South America (e.g., Kellogg 1934a, Bouetel \& Muizon 2006), the European Atlantic (e.g., Van Beneden 1880, Van Deinse 1931), Mediterranean/Tethys (e.g., Strobel 1881, Capellini 1899), Western Paratethys (e.g., Kadíc 1907, Czyzewska \& Ryziewicz 1976), southeast Europe and Caucasus (e.g., Brandt 1873, Mchedlidze 1988), Bangladesh (Anderson \& Barnes 2000), and Japan (e.g., Hatai et al. 1963, Kimura \& Ozawa 2002).

The first revised classification of the European and North American fossil mysticetes was provided by True (1912) and Winge (1921). Both evaluated and characterized the valid genera known from the $19^{\text {th }}$ century. Abel (1938, 1941) followed with an incompleted revision of the voluminous Belgian material (Van Beneden 1882, 1885, 1986).

The medium-sized extinct Balaenomorpha are paraphyletic, probably polyphyletic, with several homoplastic characters. Fragmentary preservation and parallel developments hinder the search for the ancestors from which the modern balaenopterids and balaenids arose. Progress could be achieved by several new phylogenetic analyses (e.g., Kimura \& Ozawa 2002, Bouetel \& Muizon 2006, Fitzgerald 2006, Steeman 2007, Bisconti 2008, Deméré et al. 2008; see Fig. 1). As a result, the Cetotheriidae, as mentioned above, is now restricted to a limited number of genera including, among others, Cetotherium, Herpetocetus,
Metopocetus, Mixocetus, Nannocetus, Piscobalaena (see Bouetel \& Muizon 2006, Uhen et al. 2008). The diagnostic but fragmentary late Miocene to early Pliocene fossils of Herpetocetus (Geisler \& Luo 1996, Whitmore \& Barnes 2008) could not be considered in this paper. A relatively complete skull referred to as Herpetocetus has been reported from the Pliocene of Japan (Hasagawa et al. 1985, Oishi \& Hasagawa 1994) and awaits description.

Traditionally, four families of modern mysticetes are distinguished: the Balaenopteridae (Balaenoptera + Megaptera), the Eschrichtiidae (Eschrichtius), the Balaenidae (Balaena + Eubalaena), and the Neobalaenidae (Caperea). The relationships between them were contentious before cladistic analyses based on more extensive molecular data were performed. Thereafter, the Balaenidae emerged to be the most primitve of the living mysticetes, with the Neobalaenidae as the next diverging lineage and the sister group to the Balaenopteridae-Eschrichtiidae clade (Rychel et al. 2004, Sasaki et al. 2005). Caperea marginata, the only representative of the Neobalaenidae and without any fossil record so far, was once assumed to have a close relationship to the balaenopterids because of very similar mitochondrial DNA signals (Árnason et al. 1993). Anyhow, the cranial morphology of Caperea is unique with its large extreme anteriorly thrusted supraoccipital and differs significantly from that of the balaenopterids.

Geisler \& Sanders (2003) produced, on the other hand, the first comprehensive morphology-based cladistics of fossil and living cetaceans including a significant number of taxa. Their most parsimonious tree divided the extant mysticetes into the Balaenoidea (Balaenidae $+\mathrm{Neo}-$ balaenidae) and the Balaenopteroidea (Balaenopteridae + Eschrichtiidae) which was confirmed by Deméré et al. (2005) and Fitzgerald (2006), but not by McLeod et al. (1993), Bouetel \& Muizon (2006), Steeman (2007), Bisconti (2007, 2008).

McLeod et al. (1993) listed six synapomorphies for an Eschrichtius + Balaenoidea clade: a narrow rostrum, which is arched dorsally, elevated bones around the external bony nares (regarding the cranium), and three characters concerning the dentary. Geisler \& Sanders (2003) accepted only the characters of the dentary as possible synapomorphies. They argue that the nasals and premaxillae in all extant mysticetes are equally elevated. The narrow rostrum of Eschrichtius is not as narrow as it is in balaenoids but is equal in width, relative to the width across the supraorbital processes as in Balaenoptera. So, Geisler \& Sanders (2003) interpreted a relatively narrow rostrum as a synapomorphy of the mysticete crown group, not as a synapomorphy of an Eschrichtius + Balaenoidea clade.

Bouetel \& Muizon (2006) suggested that Eschrichtius is closely related to the Balaenidae and Neobalaenidae (Fig. 1B), which is in contradiction to recent molecular studies. 
Steeman (2007) found different relationships and included several stem-balaenopterids with the Balaenopteridae in the Balaenopteroidea, and the Eschrichtiidae in a sister group relationship with the Cetotheriidae, Fig. 1G). Bisconti $(2007,2008)$ also concluded that the Eschrichtiidae are close to what he called the "Cetotherium-like cetotheres" (= Cethotheriidae sensu stricto, Fig. 1A).

The Balaenidae are morphologically quite distant from the other mysticetes with their large head, the transversally compressed and arched rostrum, and the vertically developed squamosal (McLeod et al. 1993, Bisconti 2003). Two living genera can be distinguished, but Árnason \& Gullberg (1994) could not document any particular molecular difference between the genera Balaena and Eubalaena based on cytochrome $b$. In contrast, Rosenbaum et al. (2000) actually suggested separating Eubalaena into three species. The origin of the Balaenidae still remains uncertain. Early fossil representatives are rare in comparison to balaenopterids and stem-balaenopterids. The oldest known remains of a balaenid is documented by a partial skull with associated ear bones from the late Oligocene of New Zealand (Fordyce 2002b).

The living rorquals (Balaenopteridae) comprise six to nine species of Balaenoptera (Berta et al. 2006) and the humpback whale (Megaptera novaeangliae). Characteristic morphological features of the dorsal aspect of the Balaenoptera skull are an expanded posterior end of the ascending process of the maxillae and temporal crests that overhang the posterior half of the temporal fossa. Although the unity of the genus Balaenoptera is justified today - genetically the blue whale is extremely similar to other Balaenoptera species (Árnason \& Gullberg 1993, 1994; Rychel et al. 2004; Steeman et al. 2009) - a resuscitation of the name "Sibbaldus" occurred from time to time in the literature (e.g., Miller 1923, Kellogg 1928, Simpson 1945, Pilleri 1966, Barnes \& McLeod 1984, Oishi 1997). The cranial morphology of Balaenoptera musculus is slightly different in proportion when compared to the other species. Today, such separation of the blue whale is phylogenetically not rational and also nomenclaturally wrong, because the type species of Sibbaldus is a sei whale and not a blue whale (Rice 1998).

The position of the gray whale, Eschrichtius robustus seems to be unresolved. The only extant species representing the Eschrichtiidae is nested within the Balaenopteridae according to a Bayesian phylogenetic analysis of cytochrome $b$ sequences (May-Collado \& Agnarsson 2006), which would mean a paraphyly of the Balaenopteridae as also found by Rychel et al. (2004) and Sasaki et al. (2005). On the other hand, Steeman et al. (2009) recently found Balaenopteridae to be monophyletic (excluding Eschrichtius) in an analysis based on nucleotide sequences obtained from GenBank (National Center for Biotechnology Information; Bethesda, MD). The oldest known eschrichtiid,
Eschrichtioides gastaldii, is known from the early Pliocene of northern Italy (Bisconti 2008).

Several new mysticetes close to the Balaenopteridae were discovered (erected or revised) in the past fifteen years. Some of them could be incorporated into the analysis presented here. Praemegaptera pampauensis from the middle/late Miocene of Groß Pampau in Northern Germany was erected by Behrmann (1995), but without providing a sufficient description and diagnosis. Intensive investigations reveal that there are no arguments to place this species into the humpback lineage (Hampe, in prep.). The type consists of a more or less complete skeleton, but partly heavily ruptured and fractured. Parabalaenoptera baulinensis from the late Miocene of California is characterized by, e.g., elongated nasals, a short postglenoid process, and long coronoid crest at the dentary (Zeigler et al. 1997). Protororqualus cuvieri is a probable balaenopterid from the Piacenzian (early Pliocene) of Mount Pulgnasco (N Italy), a skeleton formerly housed in the Museum of Natural History in Milan, but destroyed by bombing during World War II. This species, often reproduced in textbooks (e.g., Zittel 1918) was currently revised and renamed by Bisconti (2005). The excellent graphic documentation of this whale by Cortesi (1819) and Van Beneden (1875) allowed such detailed scientific redescription. The skull has an anteriorly pointed suproccipital, strongly developed attachment fields for the neck musculature on the dorsolateral surface of the supraoccipital, squamosals with zygomatic processes diverging away from the longitudinal axis of the cranium. Archaebalaenoptera castriarquati, also from the north Italian Piacenzian, was recognized phylogenetically by Bisconti (2007) as the most primitive balaenopterid (Fig. 1A). It differs from Balaenoptera in also having strong, robust tubercles for the neck musculature on the supraoccipital, and very long nasal bones forming a triangular interorbital region of the frontal posteriorly.

Eobalaenoptera harrisoni (Dooley et al. 2004) could not be included in the analysis here because it is known only from a partial skeleton comprising the first 28 vertebrae in a row, flipper bones, and parts of the occipital region of the skull. This specimen from the Serravallian of Virginia is interpreted to be the oldest representative of a Balaenopteridae + Eschrichtiidae clade by its authors and is positioned in polytomy with Eschrichtius and Parabalaenoptera as a sister group to the Balaenopteridae (Balaenoptera + Megaptera; Dooley et al. 2004: Fig. 9).

\section{Relative warp analysis}

The results describe the morphological changes, respectively the vectorial shifts of the landmarks defined on dorsal side of the cranium from the calculated consensus configuration. 


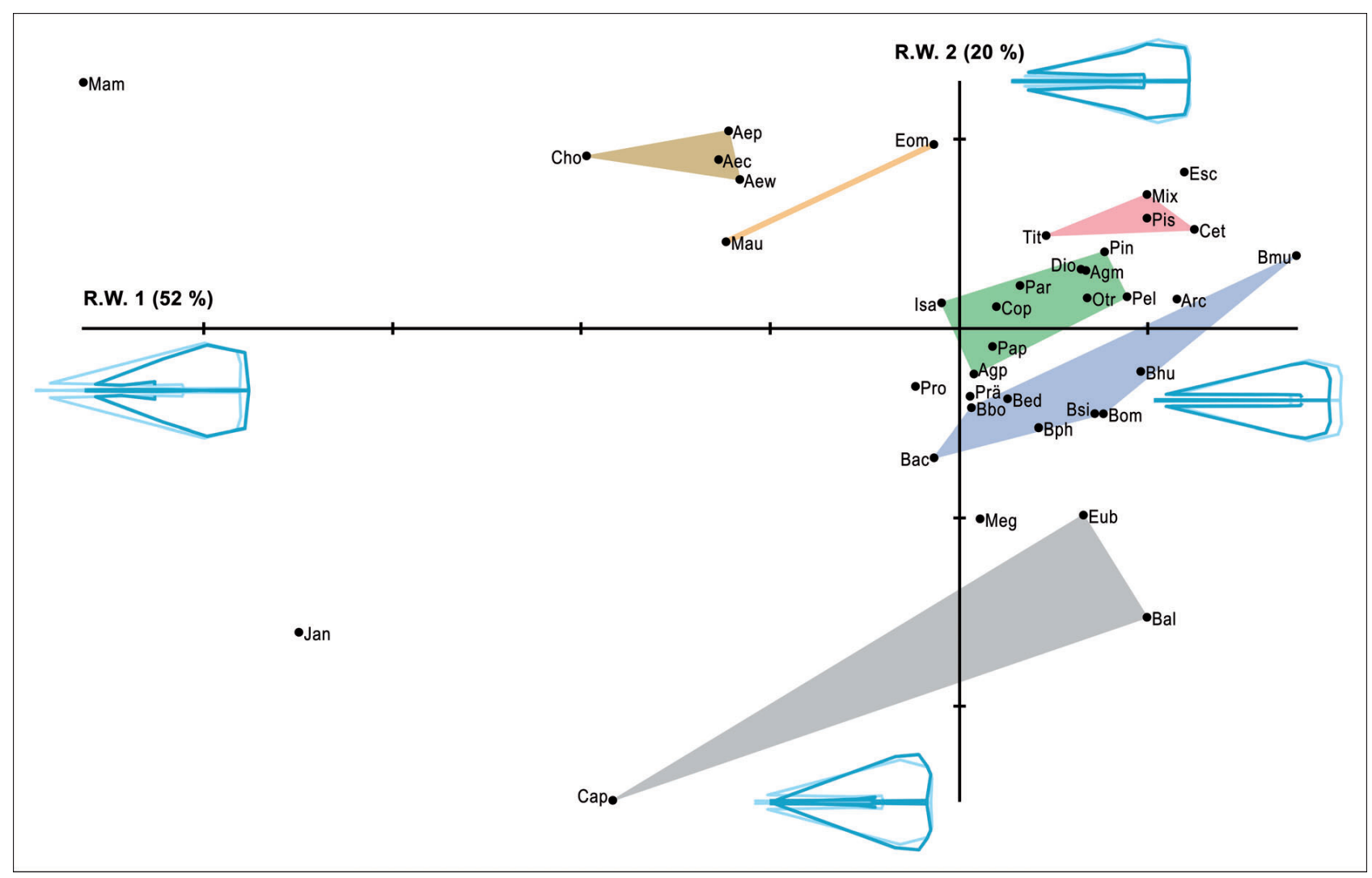

Figure 4. Relative warp analysis $1 \& 2$ of mysticete crania in dorsal view based on 38 scanned skulls of recent species and skull reconstructions of fossil taxa. The light brown area represents the Aetiocetoidea, orange the Eomysticetoidea, grey the Balaenoidea, pink the Cetotheriidae, green the stem-balaenopterids and blue the genus Balaenoptera. For abbreviations, see Table 1.

Positive values in relative warp 1 represent a truncation of the postorbital/occipital region with a moderate elongation of the rostrum and a posterior shift of the nasal region. Negative values in relative warp 1, characterize a drastic truncation of the rostum, a moderate increase of the occipital length of the skull and an anterior shift of the nasal region.

Positive relative warp 2 values describe a slight narrowing of the posterior half of the cranium with a forward shift of the zygomatic and the supraorbital processes. Furthermore, this relative warp reflects a lateral expansion of the rostral elements (premaxillae and maxillae). Negative values of relative warp 2 illustrate a lateral expansion of the postorbital region, the backward shift of the zygomatic and supraorbital processes, and a narrowing of the rostrum.

Positive relative warp 3 values express a slight narrowing of the rostrum - generally, the cranium becoming more slender and the maxillar ascending processes diverging slightly from the longitudinal axis. Correspondingly, negative relative warp 3 values describe a minor increase of the cranial outline and maxillar ascending processes approaching one another.

In order to make the information in the diagrams more pronounced and to facilitate the discussion, related whales share coloured areas according to their proposed systematic affiliation: the Aetiocetoidea (included genera Aetiocetus and Chonecetus), the Eomysticetoidea (Eomysticetus and "Mauicetus" lophocephalus), the Balaenoidea (Balaena, Eubalaena, and Caperea), the Cetotheriidae (in the current, restricted sense; see above), the stem-balaenopterids, and Balaenoptera species. It should be remembered that monophyly, paraphyly or other statements based on cladistic methods cannot be supported by the landmark analysis carried out in the present study.

We are aware of the fact that this investigation is strongly limited by the quality of preservation of the fossil specimens. It is obvious that all extant species are better documented than most of the fossils and that adding or removal of single species could cause a slightly different result. However, when comparing our clustering of species that were obtained independently from cladistic analyses to cladistic groupings, we observe vast congruencies.

\section{Relative warps $1 \& 2$}

The diagram showing relative warps $1 \& 2$ (Fig. 4) separates the primitive toothed mysticetes Janjucetus and 
Mammalodon from other mysticete taxa because of distinct shape differences. The rostrum is shorter than in the consensus configuration (R.W. 1 negative) and the posterior half of the skull of Janjucetus is much broader (R.W. 2 negative; triangular shape of cranium in dorsal view).

The Aetiocetoidea (Aetiocetus and Chonecetus) are located closely together, having a short rostrum in relationship to the postorbital/occipital region, which is in accordance with most of the cladistic analyses. A sister group relationship of Aetiocetus and Chonecetus is documented in Kimura \& Ozawa (2006), Bisconti $(2007,2008)$ and Steeman (2007) (Fig. 1A, F, G). However, Bouetel \& Muizon (2006) found that the toothed mysticetes Aetiocetus and Chonecetus do not constitute a monophyletic clade in their phylogenetic analysis. The parsimony analysis of Deméré et al. (2008) place the four species of the Aetiocetoidea investigated here in polytomy (Fig. 1C).

The Eomysticetoidea, represented by Eomysticetus whitmorei and "Mauicetus" lophocephalus, are characterized by their extremely elongated nasals, also supported by Steeman (2007) with the narrow intertemporal region as a synapomorphic character regarding the dorsal aspect of the skull.

The Balaenoidea are characterized by a lateral expansion of the orbital region and a narrowing of the rostrum (R.W. 2 negative); the neobalaenid Caperea has the shortest rostrum (R.W. 1 negative) of all specimens in the sample. The close relationship of all Balaenoidea (Balaena, Eubalaena, and Caperea) is supported by 12 unambiguous character changes (7 concerned with dorsal skull features) which were subjected to cladistic analysis by Steeman (2007). Bisconti (2008), who also included fossil representatives, confirms the monophyly of the Balaenoidea with the highest bootstrap support values $(100 \%$ in a 50 per cent majority rule tree). Fitzgerald (2006) only used Eubalaena and Caperea for his cladistic analysis (Fig. 1E), but obtained a $63 \%$ bootstrap value for this clade. However, Caperea is, in contrast, quite distant from the balaenids in the relative warp analyses. This supports some of the molecular studies placing the pygmy right whale on a different branch (e.g., Árnason et al. 1993). The balaenids with Eschrichtius as the sister group form a clade supported by 14 characters ( 7 concerned with cranial morphology) according to Bouetel \& Muizon (2006). Seven unequivocal characters support the monophyly of the Balaenoidea excluding Eschrichtius in Deméré et al. (2005).

An increased elongated rostrum (R.W. 1 positive) joins the Cetotheriidae sensu stricto (Cetotherium rathkei, Mixocetus elysius, Piscobalaena nana including also Titanocetus sammarinensis), Eschrichtius, the stem-balaeonopterids, and Balaenoptera.

The Cetotheriidae have been grouped closely together (marked by a small triangular area). The orbito-occipital part is wider than in the consensus configuration (R.W. 2 positive). Bouetel \& Muizon (2006) defined the Cetotheriidae (Cetotherium rathkei, Mixocetus elysius, and Piscobalaena nana plus three additional taxa) as a monophyletic group supported by 14 characters (with 9 characters concerning the dorsal skull morphology). Kimura \& Ozawa (2002) presented a clade consisting of Cetotherium plus Mixocetus (61\% bootstrap support value) in a sister group relationship to all other "cetotheres" (= stem-balaenopterids) (Fig. 1F). They were unable to identify any synapomorphies characterizing the Cetotheriidae in the old sense (stem-balaenopterids plus Cetothriidae sensu stricto) and concluded a paraphyly. Weak support for a monophyly of the Cetotheriidae in the former sense is also reported by Deméré et al. (2008). They came to a similar result with their cladogram (close relationship of Cetotherium rathkei and Mixocetus elysius) as Kimura \& Ozawa (2002), Bouetel \& Muizon (2006), and Bisconti (2007, 2008) (Fig. 1A-C, F). Titanocetus sammarinensis, originally described by Capellini (1901, as Aulocetus) but thoroughly reviewed by Bisconti (2006), has not yet been placed within the Cetotheriidae sensu stricto. Bisconti himself thinks that Titanocetus is closely related to Cetotherium and Mixocetus but is more primitive, due to the morphology of the supraoccipital. Our landmark analysis supports a close relationship between Titanocetus and the Cetotheriidae.

Unfortunately, the present landmark analysis shows no subdivision between the remaining stem-balaeonopterids. Steeman (2007) introduced three new families, the Aglaocetidae, the Pelocetidae, and the Diorocetidae, all belonging to Balaenopteriodea. They are exclusively defined on the morphology of the ear bones (periotic, tympanic bulla). Steeman's classification has no support here regarding the dorsal cranium. All stem-balaeonopterids cluster closely together. The members of the "Aglaocetidae" according to Steeman (Aglaocetus, Isanacetus, Pinocetus), for example, would cover a shape area containing several other species, which Steeman assigned to different families. According to our present knowledge, the view of Bisconti $(2007,2008)$ that the stem-balaenopterids form a still unnamed paraphyletic clade appears more plausable. Deméré et al. (2005) were also unable to subdivide the stem-balaenopterids from a polytomy standpoint (Fig. 1D).

In our analysis the extant gray whale Eschrichtius robustus is closest to the Cetotheriidae sensu stricto. This supports the cladistic results of Steeman (2007) and Bisconti (2007, 2008). In Bisconti's cladograms (Fig. 1A), Eschrichtius is the sister group of the Cetotheriidae. The gray whale was already previously regarded as a closely related taxon to the cetotheriids (e.g., Andrews 1914, Winge 1921, Kellogg 1928). Steeman (2007) established her result mainly on characters of the dentary. There is no support for a closer relationship between Eschrichtius (R.W. 2 


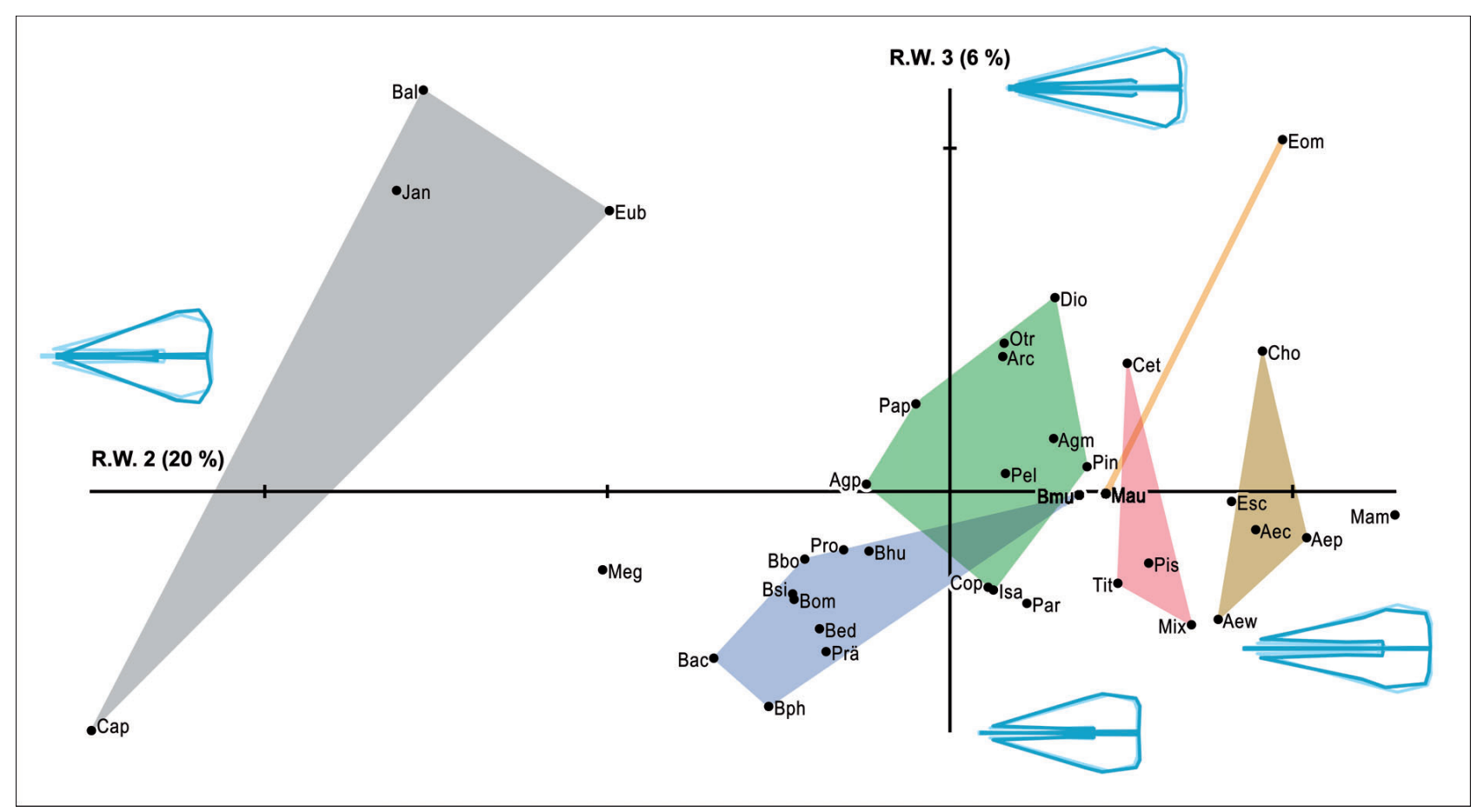

Figure 5. Relative warp analysis $2 \& 3$ of the same mysticete crania in dorsal view (for explanation, see Fig. 2).

positive) and the Balaenoidea (R.W. 2 negative) as proposed, for example, by McLeod et al. (1993). The Eschrichtiidae are nested between the Balaenopteridae and Caperea marginata in Deméré et al.'s tree $(2005,2008)$ (Fig. 1C, D), which also corresponds to recent molecular studies (e.g., May-Collado \& Agnarsson 2006). The bootstrap value for the eschrichtiid position between the balaenopterids and balaenids does not have very strong support $(53 \%)$ in a tree limited to morphological data (Deméré et al. 2005).

The species belonging to Balaenoptera primarily cover an area in the positive R.W. 1 quadrant. The distant position of the blue whale, Balaenoptera musculus, to the other species is striking. The reason is its strongly elongated rostum and a narrower postorbital (temporal) part of the skull (R.W. 1 positive, R.W. 2 positive). Overall, the unity of Balaenoptera, as mentioned above, is without doubt. The humpback whale Megaptera novaeangliae has a distinctly broader orbito-occipital area (R.W. 2 negative) and is therefore placed between Balaenoptera and the right whales. The species $B$. hubachi, initially described as belonging to Megaptera is precisely placed within the area of Balaenoptera in the relative warp analysis. This species has none of the autapomorphies of the extant humpback. Deméré et al. (2005) suggested placing that species into a different genus. Our analysis supports an affiliation to Balaenoptera.

Archaebalaenoptera castriarquati, which is interpreted to be the most basal balaenopterid by Bisconti
(2007), and Praemegaptera pampauensis display the closest position to Balaenoptera in the relative warp $1 \& 2$ score - closer than Protororqualus cuvieri, a sister taxon to Archaebalaenoptera castriarquati (Bisconti 2007, 2008) and Parabalaenoptera baulinensis, which is placed within the area of the stem-balaenopterids in this landmark analysis. Parabalaenoptera is the sister taxon of Balaenopterinae according to Zeigler et al. (1996) and Deméré et al. (2005, 2008) (Fig. 1C, D), and of the Megapterinae according to Bisconti (2007, 2008) (Fig. 1A).

\section{Relative warps $2 \& 3$}

The second diagram (Fig. 5) strongly separates the Balaenoidea (R.W. 2 negative; lateral expansion of the orbital/postorbital region) from other taxa with the exception of Janjucetus hunderi, which is placed here within the range of the modern right whales. Certainly, there is no derivation or ancestorship to conclude at this stage. Mammalodon is placed opposite to Janjucetus mainly because of the shape differences regarding the occipital part of the cranium (Janjucetus is here much broader; R.W. 2 negative, see above). The great distance of Caperea to the Balaenidae is the result of the slightly broader cranium and ascending processes of the maxillae which are closer to the cranial longitudinal axis (R.W. 3 negative).

Aetiocetoidea and Cetotheriidae have adjacent areas (R.W. 2 positive) to the living Eschrichtius, close to the 
Aetiocetoidea. R.W. 3 divides Chonecetus from Aetiocetus (see comments by Bouetel \& Muizon 2006; see above).

"Mauicetus" is not at any significant distance to Cetotheriidae and the stem-balenopterids in this diagram. Eomysticetus is quite distant to "Mauicetus" because of its distinguishable slender skull (R.W. 3 positive). All representatives of the Cetotheriidae show nearly the same value regarding the lateral expansion of the posterior half of the cranium combined with a forward shift of the zygomatic and the supraorbital processes (R.W. 2 positive). Cetotherium rathkei is separated from the other genera of the Cetotheriidae by a slender cranium (R.W. 3 positive; equivalent situation: separation of Chonecetus from the other Aetiocetoidea).

Balaenoptera and stem-balaeonopterids are situated in the vicinity of the consensus (axis crossing) with the majority of stem-balaeonopterids becoming narrower in the occipital region of the skull (R.W. 3 positive). Cophocetus and Isanacetus are placed closely together, increasing the range of the stem-balaeonopterids and overlapping with the area of Balaenoptera. The results of this diagram give, as in relative warps $1 \& 2$, no support to the newly erected families of stem-balaenopterids by Steeman (2007). Megaptera has the same value as Eubalaena (broader orbito-occipital area, R.W. 2 negative).

Praemegaptera and Protororqualus fell into the range of Balaenoptera (all R.W. 3 negative), whereas Archaebalaenoptera is placed in the stem-balaenopterid area (R.W. 3 positive: increased slenderness).

Relative warp 3 is considered to be quite weak, because the high-lighted areas are concentrated in the proximity of the R.W. 2 axis.

\section{Relative warps $1 \& 3$}

The third diagram (Fig. 6) does not reveal any clear trends or additional information to R.W. $1 \& 2$ and R.W. 2 \& 3. Mammalodon and Janjucetus were placed in a far distant position to all other species because of their extremely short skull (R.W. 1 negative). The Aetiocetoidea are still well definable; the different R.W. 3 value separates Chonecetus a little from Aetiocetus.

Eomysticetus' position is quite distant to "Mauicetus" because of its distinguishable slender skull (R.W. 3 positive, see above).

The representatives of the Cetotheriidae, the stembalaenopterids, and the genus Balaenoptera, including the humpback, merge in the R.W. 1 positive sector. The R.W. 3 value is too weak to disconnect those groups with any certainty.

Praemegaptera and Parabalaenoptera remain in the area of Balaenoptera; Protororqualus and Archaebalaenoptera are placed outside of the high-lighted sys- tematic areas. The stem-balaenopterids Parietobalaena, Cophocetus and Pelocetus, diagnosed as the new family Pelocetidae by Steeman (2007), are placed distantly (as also in the above discussed diagrams). There is no identifiable evidence for a monophyly of that group.

The neobalaenid Caperea (R.W. 1 negative/ R.W. 3 negative) drifts significantly from the Balaenidae (R.W. 1 positive/ R.W. 3 positive). Balaena and Eubalaena have a more slender cranium with a longer rostrum than Caperea.

\section{Results}

It can be demonstrated that landmark analyses can play a useful role in verifying systematic relationships to a certain degree. This study widely supports the results of several recently published cladistic analyses. The present landmarkbased morphometric study of cranial structures shows that, despite the substantial molecular data we have at our disposition today, morphology is still fundamental for systematic descriptions and communications. Although the ear bones are extremely diagnostic, e.g., $43 \%$ of the characters used by Steeman (2007) were based on the periotic and tympanic bulla, characters of the dorsal cranium yield distinct signals useful for systematic discussions. The following conclusions could be drawn from the relative warp analysis in conjunction with the recently published parsimony trees:

1. The archaic mysticetes Janjucetus and Mammalodon are placed at some significant distance from other (derived) mysticetes regarding their cranial morphology. Neither shows evidence of the typical mysticete filter-feeding. Because of their robust dentition, they are interpreted as a macrophagous predator (Janjucetus, Fitzgerald 2006) or gulp-feeder with a pleated throat (Mammalodon, Fordyce \& Muizon 2001). Janjucetus and Mammalodon are slightly younger than the representatives of the Eomysticetidae, which already prospered without functional teeth (probably absorbed in the foetal stage). Janjucetus and Mammalodon are therefore considered as highly specialized whales or may mark a dead end in mysticete evolution.

2. Janjucetus has similarities with the Balaenidae (Balaena, Eubalaena) concerning the lateral expansion of the orbital/postorbital region (R.W. 2 \& 3). According to recent knowledge, there are no clues suggesting any relationship at this stage. This point deserves closer study at a later date.

3. Aetiocetus and Chonecetus are widely accepted as sister groups, although Bouetel \& Muizon (2006) suggest paraphyly. A monophyletic Aetiocetoidea is undoubtedly supported by the relative warp analysis.

4. The toothless mysticetes of the Eomysticetoidea are quite distinct to other families (R.W. $1 \& 2,1 \& 3$ ). In addi- 


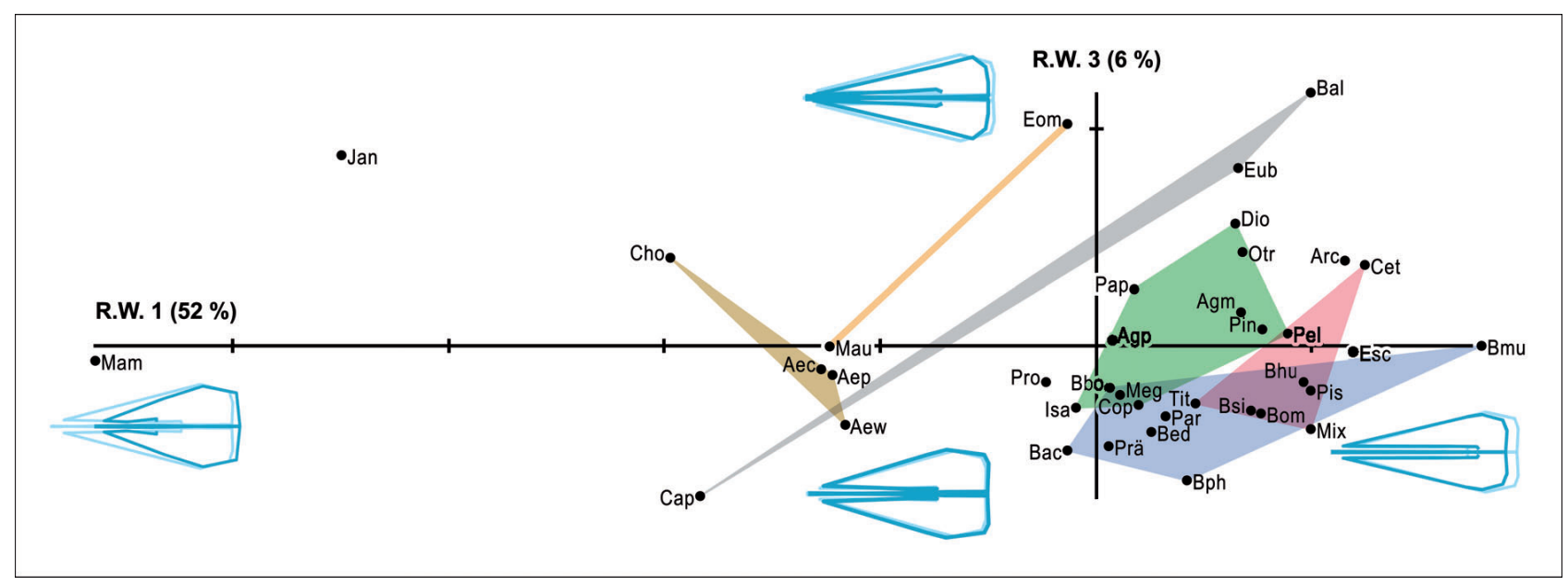

Figure 6. Relative warp analysis $1 \& 3$ of mysticete crania in dorsal view (for explanation, see Fig. 2).

tion, a morphological distance is documented (in all R.W. diagrams) between Eomysticetus whitmorei and "Mauicetus" lophocephalus. The latter is often not included in cladistic analyses (exception: Steeman 2007). The generic status of "Mauicetus" lophocephalus is unsolved (see discussion in Fordyce 1980b, 1991). A revision of the complete Mauicetus-group is needed to resolve the systematic position of the different allocated species.

5. The neobalaenid Caperea is displayed farther away from Balaena and Eubalaena than Megaptera is from Balaenoptera in all R.W. diagrams because of its strongly derived skull structure.

6 . The relative warp analysis supports a restriction of the Cetotheriidae to a limited number of genera confirming the phylogentic results of Bouetel \& Muizon (2006) and Steeman (2007). Cetotherium, Mixocetus, Piscobalaena, and Titanocetus, investigated here, are included within this family.

7. The living Eschrichtius (R.W. $1 \& 2,1 \& 3$ ) is placed in close vicinity to the Cetotheriidae which supports a sister group relationship, as was proposed by Bisconti (2007, 2008) and Steeman (2007).

8. A subdivision of the stem-balaenopterids into Pelocetidae (in this analysis the following were included: Pelocetus, Parietobalaena, Cophocetus), Aglaocetidae (included here: Aglaocetus, Isanacetus, Pinocetus), and Diorocetidae (here only Diorocetus was included) introduced by Steeman (2007) obtains no support from the dorsal skull shape characters. Graphic connections between the noted representatives would cause strongly overlapping areas in the relative warp diagrams. Moreover, the strict consensus tree of Deméré et al. (2005) shows a polytomous branching of Pelocetus, Parietobalaena, Isanacetus, Cophocetus, and Aglaocetus. This is also confirmed by Bisconti (2007) who demonstrated unsolved phylogenetic relationships between Pelocetus, Isanacetus,
Parietobalaena, and Diorocetus (polytomy in his 50\% majority rule tree).

9. Unfortunately, Paratethyal and Caucasian mysticetes were not adequately considered in former phylogenetic analyses. Our relative warp analysis of the dorsal cranium reveals the close position of Badenian (middle Miocene) Pinocetus to the Cetotheriidae. This is not surprising as Czyzewska \& Ryziewicz (1976) already pointed out similarities between Titanocetus sammarinensis (skull structure) and Mixocetus elysius (skull and axial skeleton). The middle Miocene Otradnocetus is close to Diorocetus. The holotype, Otradnocetus virodovi, is considered as monophyletic by Uhen (2010) and assigned, without comparison, to the Cetotheriidae by Pilleri (1986) and McKenna \& Bell (1997) following the old method of definition.

10. The species Balaenoptera hubachi from the early Pliocene of Chile is a smaller representative of the Balaenopteridae falling into the size range of the living B. acutorostrata (Dathe 1983). Because this species does not show any of the autapomorphies of the recent humpback (nasals, frontals, mandible, scapula), Deméré et al. (2005) suggested placing the Chilean species into a different genus. We could prove from our analysis that its dorsal skull morphology is not distinguishable from that of the range of other species of Balaenoptera. Therefore we propose including this species into Balaenoptera (B. hubachi) until a revision produces different results.

11. Based on the dorsal cranium the position of Parabalaenoptera baulinensis is not clearly interpretable. It is within the morphological range of the stem-balaenopterids (R W. 1 \& 2), and Balaenoptera (R.W. 1 \& 3), but outside the range of both groups (R.W. $2 \& 3$ ).

12. Protororqualus cuvieri has skull morphology similar to that of Balaenoptera. A close resemblance to the balaenopterids can be supported here. 
13. With exception to R.W. 1 \& 2, the shape of the dorsal skull of Archaeobalaenoptera castriarquati is morphologically not very close to that of Balaenoptera.

14. The structure of the dorsal cranium of Praemegaptera pampauensis is very close to that of Balaenoptera (R.W. $1 \& 2$ ) or within the morphological range of Balaenoptera species (R.W. 2 \& 3, 1 \& 3).

We suggest that the presented landmark analysis of the dorsal skull be considered as an independent (limited) tool which can reveal phylogenetic inferences and test hypotheses generated by other sources and methods. There is a wide consent that the earbones of cetaceans are of great importance for the discussion of phylogenetic relationships. A future study applying 3D morphometrics to the often well preserved earbones (esp. periotics) or even the complete skull might bring us one step further. We abstained from performing a relative warp analysis of the ventral cranium in the absence of sufficient number of adequately preserved fossil specimens. We regard one of the key questions in mysticete evolution to be resolution of the origin of the modern rorquals, and to identify their ancestor from the large group of stem-balaenopterids. It was not within the aims of this study to find an answer to this complex question.

\section{Acknowledgements}

We are indebted to the following collegues who gave access to the studied recent and fossil material: M. Bisconti, Livorno; D. Bohaska, Washington, D.C.; V. Bouetel and C. de Muizon, Paris; W. Eckloff and S. Füting, Lübeck/Germany; E. Fitzgerald, Melbourne; R.E. Fordyce, Dunedin/New Zealand; C. Francou and G.C. Artoni, Castell'Arquato/Italy; M. Ginter, Warsaw; G. Mchedlidze, Tblissi; G.B. Vai and C. Sarti, Bologna (throughout the long period of investigation). E. Siebert, Berlin, kindly prepared the graphics for this article. We thank the Deutsche Forschungsgemeinschaft for their generous financial support and we are grateful to M. Bisconti, Livorno, and M.E. Steeman, Copenhagen, for their thorough and helpful reviews.

\section{References}

ABEL, O. 1938. Vorlaeufige Mitteilungen ueber die Revision der fossilen Mystacoceten aus dem Tertiaer Belgiens. Bulletin $d u$ Musée Royal d'Histoire Naturelle de Belgique 14(1), 1-34.

ABEL, O. 1941. Vorläufige Mitteilungen über die Revision der fossilen Mystacoceten aus dem Tertiär Belgiens (Zweiter Bericht). Bulletin du Musée Royal d'Histoire Naturelle de Belgique 17(32), 1-29.

ADAM, P.J. \& BERTA, A. 2002. Evolution of prey capture strategies and diet in the Pinnipedimorpha (Mammalia, Carnivora). Oryctos 4, 83-107.

ALLEN, J.A. 1908. The North Atlantic Right Whale and its allies. Bulletin of the American Museum of Natural History 24, 277-329.
ANDERSON, J.S. \& BARNES, L.G. 2000. A fossil Miocene whale from the Tipam Sandstone, St. Martin's Island, Bangladesh. Oryctos 3, 79-84.

ANDERSON, P.S.L. 2008. Shape variation between arthrodire morphotypes indicates possible feeding niches. Journal of Vertebrate Paleontology 28(4), 961-969.

DOI 10.1671/0272-4634-28.4.961

ANDREWS, R.C. 1914. Monographs of the Pacific Cetacea. I. The California Gray Whale (Rhachianectes glaucus Cope). Memoirs of the American Museum of Natural History, New Series 1(5), 227-287.

ANDREWS, R.C. 1916. Monographs of the Pacific Cetacea. II. The Sei Whale (Balcenoptera borealis Lesson). 1. - History, habits, external anatomy, osteology, and relationships. Memoirs of the American Museum of Natural History, New Series 1(6), 289-388.

Árnason, Ú. \& GullberG, A. 1993. Comparison between the complete mtDNA sequences of the blue and the fin whale, two species that can hybridize in nature. Journal of Molecular Evolution 37, 312-322. DOI 10.1007/BF00178861

ÁRNASON, Ú. \& GULLBERG, A. 1994. Relationship of baleen whales established by cytochrome $b$ gene sequence comparison. Nature 367, 726-728. DOI 10.1038/367726a0

ÁrnASON, Ú., GUllbERG, A. \& JANKE, A. 2004. Mitogenomic analysis provide new insights into cetacean origin and evolution. Gene 333, 27-34. DOI 10.1016/j.gene.2004.02.010

ÁRNASON, Ú., GULlBERG, A. \& WIDEGREN, B. 1993. Cetacean mitochondrial DNA control region: sequences of all extant baleen whales and two sperm whale species. Molecular Biology and Evolution 10(5), 960-970.

BAJPAI, S. \& GINGERICH, P.D. 1989. A new Eocene archaeocete (Mammalia, Cetacea) from India and the time of origin of whales. Proceedings of the National Academy of Sciences USA 95, 15464-15468. DOI 10.1073/pnas.95.26.15464

BAKER, A.N. 1985. Pygmy right whale - Caperea marginata (Gray, 1846), 345-354. In RIDGWAY, S.H. \& HARRISON, R. (eds) Handbook of marine mammals. Volume 3. The Sirenians and baleen whales. Academic Press, London.

BARNES, L.G. \& MCLEOD, S.A. 1984. The fossil record and phyletic relationships of Gray Whales, 3-32. In JONES, M.L., SWARTZ, S.L. \& LEATHERWOOD, S. (eds) The Gray WhaleEschrichtius robustus. Academic Press, Orlando, FL.

BARNeS, L.G., Kimura, M., Furusawa, H. \& SAWAmURA, H. 1994. Classification and distribution of Oligocene Aetiocetidae (Mammalia; Cetacea; Mysticeti) from the western North America and Japan. The Island Arc 3, 392-431. DOI $10.1111 / \mathrm{j} .1440-1738.1994 . t b 00122 . x$

BASZIO, S. 2005. Korrelationen der Wirbelmorphologie mit Ökologie, Taxonomie und Allometrie rezenter und fossiler Schlangen. Courier Forschungsinstitut Senckenberg 255, 185-224.

BASZIO, S. \& WeBER, S 2002. Potentials and limits of morphometry in the understanding of squamate osteological strucutres. Senckenbergiana lethaea 82(1), 13-22.

BAYLAC, M. \& DAUFRESNE, T. 1996. Wing venation variability in Monarthropalpus buxi (Diptera, Cecidomyiidae) and the Quaternary coevolution of box (Buxus sempervirens L.) and its midge: A geometrical morphometric analysis. In MARCUS, 
L.F. Marco, C., Loy, A., NAYlor, G.J.P. \& Slice, D.E. (eds) Advances in Morphometrics. NATO Science Series A: Life Sciences 284, 285-301.

BehrmanN, G. 1995. Der Bartenwal aus dem Miozän von Gr.-Pampau (Schleswig-Holstein). Geschiebekunde aktuell 11(4), 119-126.

BenHAM, W.B. 1937. Fossil Cetacea of New Zealand. II. - On Lophocephalus, a new genus of zeuglodont Cetacea. Transactions and proceedings of the Royal Society of New Zealand 67, $1-7$.

BertA, A., SuMICH, J.L. \& KovACS, K.M. 2006. Marine Mammals: Evolutionary Biology, $2^{\text {nd }}$ Edition. 547 pp. Elsevier, Amsterdam.

BisconTI, M. 2003. Evolutionary history of Balaenidae. Cranium 20(1), 9-49.

BISCONTI, M. 2005. Taxonomic revision and phylognetic relationships of the rorqual-like mysticete from the Pliocene of Mount Pulgnasco, northern Italy (Mammalia, Cetacea, Mysticeti). Palaeontographica Italica 91, 85-108.

BisCONTI, M. 2006. Titanocetus, a new baleen whale from the middle Miocene of North Italy (Mammalia, Cetacea, Mysticeti). Journal of Vertebrate Palaeontology 26(2), 344-354. DOI 10.1671/0272-4634(2006)26[344:TANBWF]2.0.CO;2

BISCONTI, M. 2007. A new basal balaenopterid whale from the Pliocene of Northern Italy. Palaeontology 50(5), 1103-1122. DOI 10.1111/j.1475-4983.2007.00696.x

BISCONTI, M. 2008. Morphology and phylognetic relationships of a new eschrichtiid genus (Cetacea: Mysticeti) from the early Pliocene of northern Italy. Zoological Journal of the Linnean Society 153, 161-186.

DOI 10.1111/j.1096-3642.2008.00374.x

BoOKSTEIN, F.L. 1991. Morphometric Tools for Landmark Data-Geometry and Biology. 435 pp. University Press, Cambridge.

Bouetel, V. \& Muizon, C. DE 2006. The anatomy and relationships of Piscobalaena nana (Cetacea, Mysticeti), a Cetotheriidae s.s. from the early Pliocene of Peru. Geodiversitas 28(2), 319-395.

BRANDT, J.F. 1873. Untersuchungen über die fossilen und subfossilen Cetaceen Europa's. Mémoires de l'Académie Impériale des Sciences de St.-Pétersbourg, $7^{\circ}$ Sér. 20(1), 1-372.

BROWN, S.G. 1995. Balaenoptera musculus (Linnaeus, 1758) Blauwal, 748-772. In RoBineau, D., DuguY, R. \& Klima, M. (eds) Handbuch der Säugetiere Europas. Band 6: Meeressäuger. Teil I: Wale und Delphine - Cetacea. Teil IB: Ziphiidae, Kogiidae, Physeteridae, Balaenidae, Balaenopteridae. Aula, Wiesbaden.

CAPEllini, G. 1899. Balenottere mioceniche di San Michele presso Cagliari. Memorie della Reale Accademia delle Scienze dell'Istituto di Bologna, Serie V 7, 661-679.

CAPEllini, G. 1901. Balenottera Miocenica del Monte Titano, Repubblica di S. Marino. Memorie della Reale Accademia delle Scienze dell'Istituto di Bologna, Serie V 9, 237-260.

CORTESI, G. 1819. Saggi geologici degli stati di Parma e Piacenza. 165 pp. Dai Torchj del Majno, Piacenza.

CUVIER, G. 1823. Recherches sur les ossemens fossiles, où l'on rétablit les caractères des plusieurs animaux dont les révolutions du globe ont détruit les espéces. Tome cinquième,
$I^{r e}$ Partie, contenant les rongeurs, les édentés, et les mammifères marins. 405 pp. Dufour \& D’Ocagne, Paris.

CzyzewskA, T. \& RYZIEwICZ, Z. 1976. Pinocetus polonicus gen. n., sp. n. (Cetacea) from the Miocene limestones of Pinczów, Poland. Acta Palaeontologica Polonica 21(3), 259-291.

DATHE, F. 1983. Megaptera hubachi n.sp., ein fossiler Bartenwal aus marinen Sandsteinschichten des tieferen Pliozäns Chiles. Zeitschrift für geologische Wissenschaften 11(7), 813-848.

DEMÉRÉ, T.A., BERTA, A. \& MCGOWEN, M.R. 2005. The taxonomic and evolutionary history of fossil and modern balaenopteroid mysticetes. Journal of Mammalian Evolution 12(1/2), 99-143.

Deméré, T.A., McGowen, M.R., Berta, A. \& Gatesy, J. 2008. Morphological and molecular evidence for a stepwise evolutionary transition from teeth to baleen in mysticete whales. Systematic Biology 57(1), 15-37.

DOI $10.1080 / 10635150701884632$

DOOLEY, A.C. JR., FrASER, N.C. \& LuO, Z. 2004. The earliest known member of the rorqual-gray whale clade (Mammalia, Cetacea). Journal of Vertebrate Paleontology 24(2), 453-463. DOI $10.1671 / 2401$

EMLONG, D. 1966. A new archaic cetacean from the Oligocene of Northwest Oregon. Bulletin of the Museum of Natural History, University of Oregon 3, 1-51.

FITZGERALD, E.M.G. 2006. A bizarre new toothed mysticete (Cetacea) from Australia and the early evolution of baleen whales. Proceedings of the Royal Society of London B 273, 2955-2963. DOI 10.1098/rspb.2006.3664

FORDYCE, R.E. 1977. The development of the Circum-Antartic current and the evolution of the Mysticeti (Mammalia: Cetacea). Palaeogeography, Palaeoclimatology, Palaeoecology 21, 265-271. DO] 10.1016/0031-0182(77)90038-4

FORDYCE, R.E. 1980a. Whale evolution and Oligocene Southern Ocean environments. Palaeogeography, Palaeoclimatology, Palaeoecology 31, 319-336. DOI 10.1016/0031-0182(80)90024-3

FORDYCE, R.E. 1980b. The fossil Cetacea of New Zealand. New Zealand Geological Survey Report 90, 1-60.

FORDYCE, R.E. 1991. A new look at the fossil vertebrate record of New Zealand, 1191-1316. In VICKERS-RICH, P., MONAGHan, J.M., BAIRD, R.F. \& RiCH, T.H. (eds) Vertebrate Palaeontology of Australasia. Monash, Melbourne.

FORDYCE, R.E. 2002a. Oligocene archaeocetes and toothed mysticetes: Cetacea from times of transition. In FORDYCE, R.E. \& WALKER, M. (eds) Abstracts, Third Conference on Secondary Adaptation to Life in Water, Department of Geology, University of Otago, Dunedin, New Zealand, 9-13 December 2002. Geological Society of New Zealand Miscellaneous Publication 114A, 16-17.

FORDYCE, R.E. 2002b. Oligocene origins of skim-feeding right whales: A small archaic balaenid from New Zealand. Journal of Vertebrate Paleontology Supplement 22(3), 54A.

FORDYCE, R.E. 2003. Cetacean evolution and Eocene-Oligocene oceans revisited, 154-170. In PROTHERO, D.R., IVANY, L.C. \& NESBITT, E.A. (eds) From greenhouse to icehouce. The marine Eocene-Oligocene transition. Columbia University Press, New York. 
FORDYCE, R.E. \& BARNES, L.G. 1994. The evolutionary history of whales and dolphins. Annual Review of Earth and Planetary Sciences 22, 419-455.

FORDYCE, E. \& MUIZON, C. DE 2001. Evolutionary history of cetaceans: a review, 169-233. In MAZIN, J.-M. \& BUFFRÉNIL, V. DE (eds) Secondary adaptation of tetrapods to life in water. Pfeil, Munich.

Fraser, N.C. \& DoOley, A.C. 2002. Baleen whales, archaic, 73-75. In PERRIN, W.F., WÜRSIG, B. \& THEWISSEN, J.G.M. (eds) Encyclopedia of Marine Mammals. Academic Press, San Diego.

GEISLER, J.H. \& LUO, Z. 1996. The petrosal and inner ear of Herpetocetus sp. (Mammalia: Cetacea) and their implications for the phylogeny and hearing of archaic mysticetes. Journal of Paleontology 70(6), 1045-1066.

GEISLER, J.H. \& SANDERS, A.E. 2003. Morphological evidence for the phylogeny of Cetacea. Journal of Mammalian Evolution 10(1/2), 23-129. DOI 10.1023/A:1025552007291

GINGERICH, P.D. 1989. New earliest Wasatchian mammalian fauna from the Eocene of northwestern Wyoming: composition and diversity in a rarely sampled high-floodplain assemblage. University of Michigan Papers on Paleontology 28, 1-97.

Hasegawa, Y., NOKARIYA, H., SATO, J. \& OISHI, M. 1985. Part III. Fossil whale, the 1st specimen from Maesawa-cho, Iwate Prefecture, Japan. In OISHI, M., ONO, K., KAWAKAMI, T., SATO, J., NOKARIYA, H. \& HASEGAWA, Y. (eds) Pliocene baleen whales and bony-toothed bird from Iwate Prefecture, Japan (Parts I-VI). Bulletin of the Iwate Prefectural Museum 3, $148-150$.

Hatai, K., Hayasaka, S. \& Masuda, K. 1963. Some fossil tympanics from the Mizuho Period of Northern Japan. Saito Ho-on Kai Museum Research Bulletin 32, 5-17.

ICHISHIMA, H. (2005). Notes on the phyletic relationships of the Aetiocetidae and the feeding ecology of toothed mysticetes. Bulletin of the Ashoro Museum of Paleontology 3, 111-117.

JURASZ, C.M. \& JURASZ, V.P. 1979. Feeding modes of the humpback whale, Megaptera novaeangliae, in southeast Alaska. Scientific Reports of the Whales Research Institute 31, 69-83.

KADíc, O. 1907. Mesocetus hungaricus Kadíc, eine neue Balaenopteridenart aus dem Miozän von Borbolya in Ungarn. Mittheilungen aus dem Jahrbuch der Königlich Ungarischen Geologischen Anstalt 16(2), 23-91.

KellOGG, R. 1924. Description of a new genus and species of whalebone whale from the Calvert Cliffs, Maryland. Proceedings of the United States National Museum 63(15), 1-14.

KelloGG, R. 1928. The history of whales - their adaption to life in the water (concluded). The Quarterly Review of Biology 3(2), 174-208. DO1 10.1086/394300

KellogG, R. 1934a. The Patagonian fossil whalebone whale, Cetotherium moreni (Lydekker). Carnegie Institution of Washington Publication 447, 63-81.

KellogG, R. 1934b. A new cetothere from the Modelo Formation at Los Angeles, California. Carnegie Institution of Washington Publication 447, 83-104.

KeLlOGG, R. 1965. Fossil marine mammals from the Miocene Calvert Formation of Maryland and Virginia. Part 1. A new whalebone whale from the Miocene Calvert Formation. United States National Museum Bulletin 247, 1-45.
KelloGG, R. 1968a. Fossil marine mammals from the Miocene Calvert Formation of Maryland and Virginia. Part 7. A sharp-nosed cetothere from the Miocene Calvert. United States National Museum Bulletin 247, 163-173.

KELLOGG, R. 1968b. Fossil marine mammals from the Miocene Calvert Formation of Maryland and Virginia. Part 6. A hitherto unrecognized Calvert cetothere. United States National Museum Bulletin 247, 133-161.

KELLOGG, R. 1968c. Fossil marine mammals from the Miocene Calvert Formation of Maryland and Virginia. Part 8. Supplement to description of Parietobalaena palmeri. United States National Museum Bulletin 247, 175-201.

KENNETT, J.P. 1978. The development of planktonic biogeography in the southern ocean during the Cenozoic. Marine Micropaleontology 3, 301-345. DOI $10.1016 / 0377-8398(78) 90017-8$

KimuRA, T. \& OZAWA, T. 2002. A new cetothere (Cetacea: Mysticeti) from the early Miocene of Japan. Journal of Vertebrate Paleontology 22(3), 684-702.

DO1] 10.1671/0272-4634(2002)022[0684:ANCCMF]2.0.CO;2

LIPPS, J.H. \& MiTCHELL, E. 1976. Trophic model for the adaptive radiations and extinctions of pelagic marine mammals. Paleobiology 2(3), 147-155.

Loy, A., Cataudella, S. \& CorTi, M. 1996. Shape changes during the growth of the Sea Bass, Dicentrarchus labrax (Teleostea: Perciformes), in relation to different rearing conditions: An application of thin-plate spline regression analysis. In MARCUS, L.F, MARCO, C., LOY, A., NAYLOR, G.J.P. \& SLICE, D.E. (eds) Advances in Morphometrics. NATO Science Series A: Life Sciences 284, 399-405.

MACLEOD, N. 2001. Landmarks, localization, and the use of morphometrics in phylogenetic analysis, 197-233. In ADRAIN, J.M., EDGECOMBE, G.D. \& LIEBERMAN, B.S. (eds) Fossils, phylogeny, and form: An analytical approach. Kluwer, New York.

MACLEOD, N. 2002. Phylogenetic signals in morphometric data, 100-138. In MACLEOD, N. \& FOREY, P.L. (eds) Morphology, shape, and phylogeny. Taylor \& Francis, London.

MARPLES, B.J. 1956. Cetotheres (Cetacea) from the Oligocene of New Zealand. Proceedings of the Zoological Society of London 126, 565-580.

May-Collado, L. \& Agnarsson, I. 2006. Cytochrome $b$ and Bayesian inference of whale phylogeny. Molecular Phylogenetics and Evolution 38, 344-354.

DOI 10.1016/j.ympev.2005.09.019

MCHEDLIDZE, G.A. 1984a. General features of the paleobiological evolution of Cetacea. 139 pp. Oxonian Press, New Dehli.

MCHEDLIDZE, G.A. 1984b. Iskopaemyi kit iz miocenovych otlozhenii okrestnostei Stanitsy otradnaya. 64 pp. Akademija Nauk Grusinskoj SSR, Tbilisi.

MCHedLIDZE, G.A. 1988. Fossil Cetacea of the Caucasus. 124 pp. Prem Printing Press, Lucknow, India.

MCKenNA, M.C. \& BELL, S.K. 1997. Classification of mammals above the species level. 631 pp. Columbia University Press, New York.

MCLEOD, S.A., WhitMORE, F.C. \& BARNES, L.G. 1993. Evolutionary relationships and classification, 45-70. In BURNS, J.J., 
Montague, J.J. \& Cowles, C.J. (eds) The Bowhead Whale. Allen Press, Lawrence, KS.

MILLER, G.S. 1923. The telescoping of the Cetacean skull. Smithsonian Miscellaneous Collections 76(5), 1-71.

MitCHELL, E.D. 1989. A new Cetacean from the Late Eocene La Meseta Formation, Seymour Island, Antarctic Peninsula. $\mathrm{Ca}$ nadian Journal of Fisheries and Aquatic Sciences 46(10), 2219-2235.

OISHI, M. 1997. A dentary of Sibbaldus sp. from the lower Pliocene of Hiraizumi, Iwate Prefecture, northeast Japan. Bulletin of the Iwate Prefectural Museum 15, 1-10.

OISHI, M. \& HASEGAWA, Y. 1994. A list of fossil cetaceans in Japan. The Island Arc 3, 493-505.

DOI $10.1111 / \mathrm{j} .1440-1738.1994 . t b 00128 . x$

OKAZAKI, Y. 1994. A new type of primitive baleen whale (Cetacea; Mysticeti) from Kyushu, Japan. The Island Arc 3, 432-435. DOI 10.1111/j.1440-1738.1994.tb00123.x

O'KeEFE, F.R. 2002. The evolution of plesiosaur and pliosaur morphotypes in the Plesiosauria (Reptilia: Sauropterygia. Paleobiology 28(1), 101-112.

DOI 10.1666/0094-8373(2002)028<0101:TEOPAP >2.0.CO;2

OMURA, H. 1959. Bryde's whale from the coast of Japan. The Scientific Reeports of the Whales Research Institute 14(9), $1-32$.

PACKARD, E.L. \& KELlOGG, R. 1934. A new cetothere from the Miocene Astoria Formation of Newport, Oregon. Carnegie Institution of Washington Publication 447, 1-62.

PILLERI, G. 1966. Die zentralnervöse Rangstufe des Blauwals (Sibbaldus musculus Linnaeus). Cellular and Molecular Life Sciences 22(12), 849-851. DOI 10.1007/BF01897458

PILLERI, G. 1986. Beobachtungen an den fossilen Cetaceen des Kaukasus. 40 pp. Hirnanatomisches Institut, Bern.

PILLERI, G. 1989. Balaenoptera siberi, ein neuer spätmiozäner Bartenwal aus der Pisco-Formation Perus, 63-105. In PILLERI, G. (ed.) Beiträge zur Paläontologie der Cetaceen Perus. Hirnanatomisches Institut, Bern.

PLEDGE, N.S. 2005. A new species of early Oligocene cetacean from Port Willunga, South Australia. Memoirs of the Queensland Museum 51(1), 123-133.

PRITCHARD, B.G. 1939. On the discovery of a fossil whale in the older Tertiaries of Torquay, Victoria. The Victorian Naturalist 55, 151-159.

RICE, D.W. 1998. Marine mammals of the world. Systematics and evolution. Society for Marine Mammology Special Publication 4, 1-231.

ROHLF, F.J. 1997a. tpsSmall, version 1.08 (Software). State University of New York, Stony Brook.

ROHLF, F.J. 1997b. tpsRelw, version 1.13 (Software). State University of New York, Stony Brook.

Rosenbaum, H.C., Brownwell, R.L. JR., Brown, M.W., Schaeff, C., Portway, V., White, B.N., Malik, S., Pastene, L.A., Patenaude, N.J., BAKer, C.S., Goto, M., Best, P.B., Clapham, P.J., Hamilton, P., Moore, M., PAYNE, R., ROWNTREE, V., TYNAN, C.T., BANNISTER, J.L. \& DESALLE, R. 2000. World-wide genetic differentiation of Eubalaena: questioning the number of right whale species. Molecular Ecology 9, 1793-1802.

DOI 10.1046/j.1365-294x.2000.01066.x
Rothausen, K. 1971. Cetotheriopsis tobieni n. sp., der erste paläogene Bartenwal (Cetotheriidae, Mysticeti, Mamm.) nördlich des Tethysraumes. Abhandlungen des Hessischen Landesamtes für Bodenforschung 60, 131-148.

RYCHEL, A.L., REEDER, T.W. \& BERTA, A. 2004. Phylogeny of mysticete whales based on mitochondrial and nuclear data. Molecular Phylogenetics and Evolution 32, 892-901.

DOI 10.1016/j.ympev.2004.02.020

SAMUELS, J.X. \& VALKENBURGH, B. VAN 2009. Craniodental adaptations for digging in extinct burrowing beavers. Journal of Vertebrate Paleontology 29(1), 254-268.

SANDERS, A.E. \& BARNES, L.G. 2002a. Paleontology of the late Oligocene Ashley and Chandler Bridge Formations of South Carolina, 2: Micromysticetus rothauseni, a primitive cetotheriid mysticete (Mammalia: Cetacea). Smithsonian Contributions to Paleobiology 93, 271-293.

SANDERS, A.E. \& BARNES, L.G. 2002b. Paleontology of the late Oligocene Ashley and Chandler Bridge Formations of South Carolina, 3: Eomysticetidae, a new family of primitive mysticetes (Mammalia: Cetacea). Smithsonian Contributions to Paleobiology 93, 313-356.

SARÀ, M. 1996 A Landmark-based morphometrics approach to the systematics of Crocidurinae: A case study on endemic shrews Crocidura sicula and C. canariensis (Soricidae, Mammalia). In MARCUS, L.F, MARCO, C., LOY, A., NAYLOR, G.J.P. \& SLICE, D.E. (eds) Advances in Morphometrics. NATO Science Series A: Life Sciences 284, 335-344.

SASAKI, T., NiKAIDO, M., HAMILTON, H., GOTO, M., KATO, H., KANDA, N., PASTENE, L.A., CAO, Y., FORDYCE, R.E., HASEGAWA, M. \& OKADA, N. 2005. Mitochondrial phylogenetics and evolution of mysticete whales. Systematic Biology 54, 77-90. DOl 10.1080/10635150590905939

SIMPSON, G.G. 1945. The principles of classification and a classification of mammals. Bulletin of the American Museum of Natural History 85, 1-350.

STAYTON, C.T. \& RUTA, M. 2006. Geometric morphometrics of the skull roof of stereospondyls (Amphibia: Temnospondyli). Palaeontology 49(2), 307-337.

DOI 10.1111/j.1475-4983.2006.00523.x

STEEMAN, M.E. 2007. Cladistic analysis and a revised classification of fossil and recent mysticetes. Zoological Journal of the Linnean Society 150, 875-894.

DOI 10.1111/j.1096-3642.2007.00313.x

SteEMAn, M.E., HebsgaArd, M.B., FordyCE, R.E., Ho, S.Y.W., RABOSKY, D.L., NIELSEN, R., RAHBEK, C., GlenNer, H., Sørensen, M.V. \& WillersleV, E. 2009. Radiation of extant cetaceans driven by restructuring of the oceans. Systematic Biology 58(6), 573-585.

DOI $10.1093 /$ sysbio/syp060

STROBEL, P. 1881. Iconografia comparata delle ossa fossili del gabinetto di storia naturale dell'università di Parma. Fascicolo I. Balenotteride (Cetoterio e Megattera?). 32 pp. Luigi Battei, Parma.

THEODOR, J.M. 2004. Molecular clock divergence estimates and the fossil record of Cetartiodactyla. Journal of Paleontology 78(1), 39-44.

DO] 10.1666/0022-3360(2004)078<0039:MCDEAT>2.0.CO;2

THEWISSEN, J.G.M., COOPER, L.N., CleMENTZ, M.T., BAJPAI, 
S. \& TIWARI, B.N. 2007. Whales originated from aquatic artiodactyls in the Eocene epoch of India. Nature 450, 1190-1194. DOI 10.1038/nature06343

TRUE, F.W. 1904. The whalebone whales of the Western North Atlantic, compared with those occuring in the European waters with some observations on the species of the North Pacific. Smithsonian Contributions to Knowledge 33, 1-332.

TRUE, F.W. 1912. The genera of fossil whalebone whales allied to Balaenoptera. Smithsonian Miscellaneous Collections 59(6), 1-8.

UHEN, M.D. 1998. Middle to late Eocene basilosaurines and dorudontines, 29-61. In THEWISSEN, J.G.M. (ed.) The emergence of whales. Plenum, New York.

UHEN, M.D. 2010. Mark D. Uhen's opinions. The Paleobiology Database, http://www.paleodb.org/cgi-bin/bridge.pl?action= displayReference\&reference_no $=12845$

UHEN, M.D., FORDYCE, R.E. \& BARNES, L.G. 2008. Mysticeti, 607-628. In JANIS, C.M., GUNNELL, G.F. \& UHEN, M.D. (eds) Evolution of Tertiary mammals of North America. Volume 2: Small mammals, xenarthrans and marine mammals. University Press, Cambridge.

VAN BENEDEN, P.J. 1875. Le squelette de la Baleine fossile du Musée de Milan. Bulletins de l'Académie Royale des Sciences, des Lettres et des Beaux-Arts de Belgique, $2^{\text {me }}$ Sér. 40(12), 736-758.

VAN BENEDEN, P.J. 1880. Les Mysticètes à courts fanons des sables des environs d'Anvers. Bulletins de l'Académie Royale des Sciences, des Lettres et des Beaux-Arts de Belgique, $2^{\text {me }}$ Sér. 50, 11-25.

VAN BENEDEN, P.J. 1882. Description des ossements fossiles des environs d'Anvers. Troisième Partie. Cétacés, Genres: Megaptera, Balaenoptera, Burtinopsis \& Erpetocetus. Annales du Musée Royal d'Histoire Naturelle de Belgique 7, 1-90 + atlas with 70 pls.

VAN BENEDEN, P.J. 1885. Description des ossements fossiles des environs d'Anvers. Quatrième Partie. Cétacés, Genre: Plesiocetus. Annales du Musée Royal d'Histoire Naturelle de Belgique 9, 1-40 + atlas with 30 pls.
VAN BENEDEN, P.J. 1886. Description des ossements fossiles des environs d'Anvers. Cinquième Partie. Cétacés, Genres: Amphicetus, Heterocetus, Mesocetus, Idiocetus et Isocetus. Annales du Musée Royal d'Histoire Naturelle de Belgique 13, $1-139+$ atlas with 75 pls.

VAN BENEDEN, P.J. \& GeRVAIS, P. 1868. Ostéographie des Cétacés vivants et fossiles comprenant la description et l'Iconographie du squelette et du système dentaire de ces animaux ainsi que des documents relatifs a leur histoire naturelle. 634 pp. Bertrand, Paris.

VAn Deinse, A.B. 1931. De fossiele en recente Cetacea van Nederland. 304 pp. H.J. Paris, Amsterdam.

VAN VALEN, L. 1968. Monophyly or diphyly in the origin of whales. Evolution 22(1), 37-41. DO1 10.2307/2406647

WADA, S., OISHI, M. \& YAMADA, T.K. 2003. A newly discovered species of living baleen whale. Nature 426, 278-281. DOI 10.1038/nature02103

WHITMORE, F.C. JR. \& BARNES, L.G. 2008. The Herpetocetinae, a new subfamily of extinct naleen whales (Mammalia, Cetacea, Cetotheriidae). In RAY, C.E., BOHASKA, D.J., KORETSKY, I.A., WARD, L.W. \& BARNES, L.G. (eds) Geology and Paleontology of the Lee Creek Mine, North Carolina, IV. Virginia Museum of Natural History Special Publication 14, 141-180.

WhitMORE, F.C. JR. \& SANDERS, A.E. 1976. Review of the Oligocene Cetacea. Systematic Zoology 25(4), 304-320. DOI $10.2307 / 2412507$

WINGE, H. 1921. A review of the interrelationships of the Cetacea. Smithsonian Miscellaneous Collections 72(8), 1-97.

Zeigler, C.V., Chan, G.L. \& BARNeS, L.G. 1997. A new Late Miocene balaenopterid whale (Cetacea: Mysticeti), Parabalaenoptera baulinensis (new genus and species) from the Santa Cruz Mudstone, Point Reyes Peninsula, California. Proceedings of the California Academy of Sciences 50(4), 115-138.

ZITTEL, K.A. VON 1918. Grundzüge der Paläontologie (Paläozoologie). II. Abteilung: Vertebrata. 675 pp. Oldenbourg, Munich. 